\title{
(Re-Defining) The Trust of the Specifically Enforceable Contract of Sale - The Vendor Purchaser Constructive Trust
}

\author{
JACOB J. MEAGHER* \\ "...the rule in the law of vendor and purchaser which used to be stated, with disarming inaccuracy, that between \\ contract and conveyance a vendor of land became a trustee of the land for his purchaser, who became a trustee of the \\ purchase money for his vendor" \\ Meagher, Gummow, and Lehane, Equity: Doctrines and Remedies (Butterworths, 1975) [329].
}

[1] This paper provides a comprehensive outline and consequential redefinition of the oldest form of constructive trust occurring in English law, ${ }^{2}$ the vendor-purchaser constructive trust (VPCT). This species of constructive trust arises by operation of law, once primarily in the context of sales of land but now in the context of any specifically enforceable contract of sale (e.g. shares in a private company). ${ }^{3}$ The VPCT primarily protects the interest and equities that each party to the contract has in its performance, ${ }^{4}$ and exists as an equitable consequence of the contract. It embodies both proprietary interests and a mutuality of obligations between vendor and purchaser, constructive trustee and beneficiary. This trust springs from Equity's ${ }^{+}$doctrinal foundations and, so far, suffers from a paucity of generalised analysis. This paper clarifies and identifies the key elements of the VPCT, rejecting the current orthodoxy and restating the trust's principle by isolating Equity's techniques - contract formation, through to equitable-conversion of title, equitable interests, lien and enforcement to final conveyance - until this doctrine is manifestly unambiguous.

\section{Constructive Trust Outlook}

[2] It is now almost pure rhetoric that in this jurisdiction a constructive trust, as defined by Lord Browne-Wilkinson, "arises by operation of law as from the date of the circumstances which give rise to it. The function of the court is merely to declare that such trust has arisen in the past. The consequences that flow from such trust having arisen ... are also determined by rules of law, not under a discretion". 5 That this dictum is so well known belies the fact that it is neither definition nor explanation for the trust's occurrence but is simply a generalisation as to the approach of Chancery when facing similar pleadings. Chancery scholars and practitioners know not the consequences of the VPCT's manifestation, nor when it presents itself, and this ill-understood jural reality ${ }^{6}$ undermines the entire constructive trust doctrine and its settled proprietary consequences.

\footnotetext{
* A version of the paper was published in Trusts \& Trustees (24) 3 266-297, No. 3, April 2018.

+ An attempt has been made to use a capital letter on Equity when emphasising the Chancery jurisdiction in contrast to its Common Law counterpart; otherwise, a lowercase equity indicates its usage in practice (i.e. a mere equity).

${ }^{1}$ Meagher, Gummow, and Lehane, Equity: Doctrines and Remedies (Butterworths, 1975) [329].

${ }^{2}$ A.J. Oakley, Constructive Trusts ( $1^{\text {st }}$ ed., Modern Legal Studies, Sweet \& Maxwell 1978) 112.

${ }^{3}$ Gosper v. Sawyer (1985) 160 CLR 584 (HCA) per Mason and Deane JJ, 568-569; Neville v. Wilson [1996] All ER 171; Michaels v. Harley House (Marylebone) Ltd [2000] Ch. 104.

${ }^{4}$ P.G. Turner, "Understanding the Constructive Trust between Vendor and Purchaser" (2012) 128 LQR, 584.

${ }^{5}$ Westdeutsche Landesbank Girozentrale v. Islington LBC [1996] UKHL 12; [1996] AC 669, 714-715 per Lord BrowneWilkinson. (My emphasis).

${ }^{6}$ Relating to rights and obligations: See Roscoe Pound, Social Control Through Law (Yale University Press, 1942) xxxvxxxvi.
} 
[3] Some five prior to handing down the Westdeutsche Landesbank decision, Sir Nicholas BrowneWilkinson held that " $[\mathrm{f}]$ ar from being based on the intention of the parties, equity imposes a [constructive] trust on a malefactor against his intention", f frequently doing so where "the malefactor intends to hold the property for himself [and] equity imposes the constructive trust against his intention". ${ }^{8}$ The VPCT is a species of general constructive trust principles but so nuanced that one might wonder if such generalisations are more hindrance than help. Sir Nicholas noted that the law of constructive trusts "has been distorted with the inevitable consequences which flow whenever the law departs from principle", 9 and this situation has not improved in the intervening years. One might reasonably ask - 'what is this principle?'. Professor Virgo argues that the VPCT is unlike all other constructive trusts insofar as it cannot be explained by reference to unconscionability; however, in contrast, while the trust arises prior to any unconscionable factor occurring it is only ever relied on if one party denies their original intention or obligation, it protects a betrayal, and therefore the unconscionability thread still rings true throughout all constructive trusts. ${ }^{10}$ There is an element of protecting each party's interest in not having their trust being betrayed and, at the end, the courts role is to crystallise this protection by way of a declaration. Albeit the 'trust' at the start, known as the VPCT, is somewhat ambiguous in its rationale, from a forward-looking perspective, at least until it is declared as existing at the end by the backwards looking, retrospective inquiry of the Court.

[4] The approach this paper takes can be attributed to a commentator who was palpable in opprobrium as "[w] hat, it seems [at least to R.P. Meagher, QC.], is going wrong in the field of English Equity, is that neither the question of roots in past precedent, nor roots in established doctrine, really seems to trouble the judges at all". ${ }^{11}$

\section{The rationale for the VPCT?}

[5] Every parcel of land is unique, and courts of Equity often protect agreements to purchase land or interests in land with orders for specific enforcement, considering damages an inadequate remedy. ${ }^{12}$ The protection and furtherance of these agreements is part of the trust's purpose. As these sale contracts can be specifically enforced in Equity, ${ }^{13}$ "Equity treats them, for many purposes, as if they were done"; 14 that is, completed. This conceptual tautology behind all constructive trusts is Equity's primary maxim. Orthodox case law, without much explanation, regards the vendor as already holding the sale property on trust for the purchaser to the extent necessary to protect the interests of both parties until all elements of the contract have been performed; i.e., until the land or unique personalty has been conveyed and the price paid. ${ }^{15}$

\footnotetext{
${ }^{7}$ The Rt. Hon. Sir Nicholas Browne-Wilkinson, "Constructive Trusts and Unjust Enrichment" (1991) Speech given to The Holdsworth Club of the University of Birmingham, 5.

${ }^{8}$ Ibid.,

${ }^{9}$ Ibid.,

${ }^{10}$ G. Virgo, The Principles of Equity and Trusts (2 ${ }^{\text {nd }}$ ed., Oxford, 2016) 325.

${ }^{11}$ Sir Robert Megarry and R. P. Meagher, Q.C., Wither Equity? And Future Directions in Equity (NSW: CLIP, 1985) 21: Roderick Pitt 'Roddy' Meagher QC, judge and author of the ground-breaking Meagher, Gummow, and Lehane, Equity: Doctrines and Remedies (1 $1^{\text {st }}$ ed., Butterworths, 1975).

${ }^{12}$ Oughtred v. IRC [1960] AC 206.

${ }^{13}$ Gosper v. Sawyer (1985) 160 CLR 584 (HCA) per Mason and Deane JJ, 568-569.

${ }^{14}$ Anonymous, A Manual of Equity Jurisprudence, as Administered in England, founded on the "Commentaries of Joseph Story", and comprising a numerous collection of points constantly occurring in "The General Practice of a Solicitor by Josiah W. Smith" (London: V. and R. Stevens and G. S. Norton, 1845) 118; John McGhee (eds.) Snell's Equity (33'rd ed., Sweet \& Maxwell, 2016) 5-015; See Banks v. Sutton (1732) 24 ER 922; (1732) 2 P.Wms 700, 715, per Sir Joseph Jekyll.

${ }^{15}$ Lady Foliamb's Case, cited in Davie v. Beversham (1661) 3 Chan. Rep. 4, Nels. 76 and 1 Chan. Cas. 39; Penn v Lord Baltimore (1750) 1 Ves Sen 444, 27 ER 1132; Banks v. Sutton (1732) 24 ER 922; (1732) 2 P.Wms 700, 715 per Sir Joseph Jekyll; Green v. Smith (1738) 1 Atk. 527, 573; Wall v. Bright (1820) 1 Jac \& W 494, 503 per Plumer MR; Nives v. Nives (1880) 15 Ch D 649; Lyell v. Kennedy (1883) App Cas 217; Basset v. Nosworthy (1883) Rep t Finch 102; Paine v. Meller (1801) 6 Ves 349; Shaw v. Foster (1872) 5 HL 321; Inland Revenue Commissioners v. G Angus \& Co. (1889) 23 QBD 579 , 596 per Lindley LJ; Tasker v. Small (1837) 3 My \& C 63, 70 per Lord Cottenham LC; Rayner v. Preston (1881) 18 ChD 13; Ridout v. Fowler (1904) 1 Ch 658; Hillingdon Estates Co. v. Stonefield Estates Ltd. [1952] Ch. 627, 632 per Vaisey J; London and Cheshire Insurance Co Ltd. v Laplanrene Property Co. Ltd. [1971] Ch 499; Jerome v. Kelly [2004] UKHL 25; Scott v. Southern Pacific Mortgages [2014] UKSC 52.
} 
[6] Sir George Jessel MR, in a case outlining the equitable doctrine of conversion, ${ }^{16}$ insisted that, and without qualification: ${ }^{17}$

"The effect of a contract of sale has been settled for more than two centuries $[\ldots]$ What is that doctrine? It is that the moment you have a valid contract for sale the vendor becomes in equity a trustee for the purchaser of the estate sold, and the beneficial ownership passes to the purchaser."

[7] Later commentators suggest this is too general and generous. ${ }^{18}$ It is so malleable in meaning as to provide no certainty when pled or opposed. The VPCT provokes reflection as to the cogency of our understanding of equitable principles. The VPCT's simple and longstanding effect, when questioned, does not marry well with settled rudiments. Revisionary Equity recognises that the purchaser's interest in receiving the land (or unique property) and the vendor's interest in receiving the price must both be protected, yet has trouble articulating how. ${ }^{19}$

[8] The jural relationships of the doctrine of conversion, ${ }^{20}$ specific performance, contract, lien and the categories of equitable interests arising out of this nuanced species of constructive trust intermingle to bring about the end that Sir George suggests, albeit by different means. The Supreme Court's decision in Scott v. Southern Pacific ${ }^{11}$ questions the result which Sir George, and indeed Equity, considers wholly settled: that the purchaser holds beneficial ownership. ${ }^{22}$

[9] More so than in any other field of law individuals feature prominently in constructive trusts discourse and definition. Sir George's influence on the law of VPCTs started before his tenure on the bench, in a case only discovered by another constructive trust luminary, "the industry of $\mathrm{Mr}$. Millett". ${ }^{23}$ The then Solicitor-General, Sir George, put forward the submission in the House of Lords that "after a contract for the sale of an estate, if the vendor sells to another person for valuable consideration he is accountable for the money as a trust". ${ }^{24}$ However, there are nuanced difficulties to examine with each of his statements, as a general definition is only useful in a general sense, and misleading in others. I suggest that Underbill and Hayton avoid the term VPCT altogether, instead deferring to the more technical "constructive trusts imposed on property that is subject to a specifically enforceable contract of sale". ${ }^{25}$

[10] This area is rich in terminology and ripe with contradictions as to the correct nomenclature. ${ }^{26} \mathrm{Dr}$ Turner emphasises the "proviso" of "linguistic propriety", asking prosaically "whether a 'trust' exists depends on the purpose for which the question is asked", with each scholar "owe[ing] a duty to give them sense". ${ }^{27}$ Respectfully, whether a trust exists also depends on its practical import and

\footnotetext{
${ }^{16}$ Jerome v. Kelly [2004] UKHL 25, [2004] 1 WLR 1409, [30] (henceforth Jerome). This is how Lord Walker categorises Lysaght v. Edwards.

${ }^{17}$ Lysaght v. Edwards (1876) 2 ChD 499, 506; Nelson v. Greening \& Skyes (Builders) Ltd [2008] 1 EGLR 59.

${ }^{18}$ Sarah Worthington, Proprietary Interests in Commercial Transactions (Clarendon Press, 1996) 188; Turner (n 3) 582; William Swadling, "The Vendor-Purchaser Constructive Trust" in Simone Degeling and James Edelman (eds.) Equity in Commercial Law (Lawbook Company, 2005).

${ }^{19}$ In terms of articulation, the adjective 'constructive' derives not from 'construct' but from 'construe' and it has been suggested that the court 'construes circumstances in the sense that it explains or interprets them; it does not construct them'; per A.W. Scott, M.L. Ascher, W.F. Fratcher, Scott on Trusts (4 ${ }^{\text {th }}$ ed., 1989) Vol 5, [462.4], as approved in Giumelli v. Giumelli (1999) 196 CLR 101, 111; See P.W. Young (eds.), On Equity (Lawbook Company, 2009) para 6.640.

${ }^{20}$ Sir Edward Sugden, A Practical Treatise of the Law of Vendors and Purchasers of Estates, $\left(10^{\text {th }}\right.$ London ed., 3 vols, 1843) 213, [39].

${ }^{21}$ Scott v. Southern Pacific Mortgages [2014] UKSC 52 (henceforth Scott); For which Professor Dixon in his editorial entitled "Why?" opines that for some the decision "... amounts to a rejection of what (we might have thought) is the core principle found in Walsh v Lonsdale": "Why?" (2014) Conv 641.

22 Jamie Glister and James Lee, Hanbury \& Martin: Modern Equity (20 ed., Sweet \& Maxwell, 2015) 277.

${ }^{23}$ Mr. P.J. Millett Q.C., for the second defendant in Lake v. Bayliss \& Ors [1974] 1 WLR 1073.

${ }^{24}$ Shaw v. Foster (1872) LR 5 HL 321, 327, citing Daniels v. Davison. Sir George's point accepted by the House.

${ }^{25}$ D. Hayton, C. Mitchell, P. Matthews (ed.), Underhill and Hayton: Law Relating to Trusts and Trustees $\left(19^{\text {th }}\right.$ ed., LexisNexis 2016) pt 31.

${ }^{26}$ Sir Peter Millett, "Restitution and Constructive Trusts" (1998) 114 LQR 399, 404: Millett (in academic writing) argues that the label 'constructive trustee' derives from the specific enforceability of the contract and does not reflect the true position of a constructive trust, although his judicial position is different (Dubai Aluminium co v. Salaam [2002] UKHL 48, [143]; Paragon Finance plc v. DB Thakerar \& Co [1999] 1 All ER 400, 408-409); Hopkins, The Informal Acquisition of Rights in Land, (Sweet \& Maxwell, 2000) 64.

${ }^{27}$ Turner (n 4) 582.
} 
application of administration, objects and subjects. The vendor has been variously described as "a trustee in a qualified sense only" 28 or as "a quasi-trustee". ${ }^{29}$ The equitable interests of both vendor and purchaser are specific ${ }^{30}$ and restricted by the contract under which the trust arises. Constructive trust musings need to be cast aside if a more rigorous analysis is to be undertaken of the instances of the constructive trust, species by species.

\title{
Certainty of Subject Matter - What is held on Trust?
}

The first edition of Meagher, Gummow and Lehane reminds us that:

\begin{abstract}
"The truth is that the equity conscience elicited varying resolutions of competing or inconsistent interests and doctrine was tempered with pragmatism. But to perceive the general operation of the equity jurisdiction there is no better vantage point than that contemplating the attempts made in the past and still undertaken to rationalize and administer a group of so-called proprietary interests ... consideration is given to attempts to isolate indicia of [them]' 31
\end{abstract}

[11] All trusts, even constructive ones, require certainty as to their subject matter, ${ }^{32}$ yet identifying the subject matter of the VPCT is a hard thing to do. It would be very convenient to accept that the subject matter of the VPCT is the same as that of the contract which brought the trust into existence (e.g. the land), yet when the stage for conveyance draws near this proves difficult as the property is held on bare trust (the bare legal estate in Vendor, the entire beneficial estate in Purchaser). ${ }^{33}$ Two alternative candidates emerge. The first is the contract (comprising its terms, obligations, rights, and more specifically the power to convey and the power to compel payment). ${ }^{34}$ The second candidate is conceptually more complex yet supported by the case law: the subject matter of the VPCT is the equities which arise between the contractual parties, and these are further delineated. Regarding the second candidate it is Dr Turner's thesis that "[t]he equities that arise between vendor and purchaser aggregate together as an equitable property", are distributed between the parties and all, bar the purchaser's lien, protect and further the contract's performance. ${ }^{35}$ This is not the same as saying that these equities are the subject matter but it does provide a foundation to be built upon. Dr Turner's answer, is that of the equities which arise, and I suggest that these are interests held on trust, the primary two are (i) the purchaser's interest in the land acquired upon contract formation, enforceable against the vendor and a gratuitous recipient, and (ii) the vendor's lien, which binds the land both while the purchaser is owner and if conveyed to a third party. Should the vendor enforce the lien a judicial sale of the land occurs, the proceeds being the balance which the purchaser promised to pay. ${ }^{36}$

\footnotetext{
${ }^{28}$ Rayner v. Preston (1881) 18 Ch D 1, 6, per Cotton LJ.

${ }^{29}$ Cumberland Consolidated Holdings Ltd v. Ireland [1946] KB 264, 269, per Lord Greene MR.

${ }^{30}$ See Dr Turner's article (referenced throughout).

${ }^{31}$ Meagher, Gummow, and Lehane (1975) (n 1) [401].

32 J. Goldsworth, "Certainty of Subject Matter" (2007) Trusts \& Trustees 13(10) 613-614; Re London Wine Co (Shippers) [1986] PCC 121; See George P. Costigan, "The Classification of Trusts as Express, Resulting, and Constructive" (1914) Harvard Law Review (27), 449-452. All except perhaps the personal liability to account as constructive trustee Giumelli v. Giumelli (1999) 196 CLR 101, for which I exclude them from being true constructive trusts; see Watson, The Duty to Account (Federation Press, 2016); An opposing view from D.W. Waters "The Role of the Trust Treatise in the 1990's" (1994) 5 Missouri Law Review 122, 141: "[t]he three certainties ... are not doctrinal axioms for a valid trust; they are administrative requirements only..." and one which the CT can arise to fix.

${ }^{33}$ Chang v. Registrar of Titles (1976) 137 CLR 177, 184; Lloyds Bank Plc v Carrick [1964] 4 All ER 630; M. Thompson, "The widow's plight - Lloyds Bank Plc v Carrick" (1996) Conv. 295; N. Hopkins, "Acquiring Property Rights from Uncompleted Sales of Land" (1998) 61(4) MLR 486, Cf Baker v Craggs [2016] EWHC 3250 (Ch).

${ }^{34}$ Professor Hudson similarly argues that the purpose of the VPCT in Jerome v. Kelley was "to ensure equitable protection for the purchaser's contractual rights until the transfer is formally completed by means of registration": A. Hudson, Equity and Trusts ( $8^{\text {th }}$ ed., Routledge, 2014) 653; for a discussion on trusts of powers See Geraint Thomas, Thomas on Powers $\left(2^{\text {nd }}\right.$ ed., OUP, 2012) [1.06]; Tasarruf Mevduati Sigorta Fonu v. Merrill Lynch Bank \& Trust Co (Cayman) Ltd [2011] UKPC 17, [44]; Clayton v. Clayton [2016] NZSC 29; Re Triffit's Settlement [1957] Ch 852, 861; In Re Watts [1931] 2 Ch 302, 305.

35 Turner (n 4) 584.

${ }^{36}$ Ibid., 582, 602.
} 
[12] Often Chancery practitioners mean equities in the usual Hohfeldian sense, i.e. immunities, liabilities, rights, powers, privileges and duties ${ }^{37}$ existing in Equity the jurisdiction, e.g. the purchaser's right or equity that the vendor not sell to another. Yet while we conceptualise these separate equities which arise at different stages, ${ }^{38}$ with each assigned a priority - aggregating loosely to 'the equitable interest' 39 - due to our lax and indeterminate use of language and terms references to the purchaser being 'beneficially entitled' or having 'beneficial title' often tell us nothing more than that they do not have legal title, ${ }^{40}$ it is a poor definition by exclusion. However, from the perspective of the vendor 'trustee' these are not general trustee duties but restrictive constructive trustee duties and should not be confused. ${ }^{41}$ On strict construction holding beneficial title means the entire equitable estate is beneficially vested, ${ }^{42}$ which is almost never the case ${ }^{43}$ and is not the sense used here. The VPCT reminds us of this distinction, and practitioners use 'interest' in multiple senses, and when delineated, four usages emerge:

(i) Beneficial title (the title split), illustrated by conversion, when the purchaser 'obtains' equitable/beneficial title/estate to the property, as opposed to legal title (but beneficial title is not his absolutely);

(ii) Equitable interests, ${ }^{44}$ when these rights can be assigned and bind third parties, but all need not be obtained or extinguished for someone with equitable title to demand legal title be conveyed (although often the proprietary ones do);

(iii) "Mere equity" interests, fragile rights not easily explained as personal or proprietary 45 but which often fit the definition of a "right to make an election which, once made, has proprietary consequences" but which before election have no proprietary consequences unless protected by an injunction; ${ }^{46}$

(iv) Chose in action, a thing recoverable by an action, a personal right of property which can only be claimed or enforced by an action (such as going to court and seeking a declaration), and not by taking possession. ${ }^{47}$ Or in simple terms, 'something' that one must sue on to enforce and by doing so this crystallises the right, often by acquiring a declaration.

[13] Dr Robert Chambers compared the established mere equity a person who rescinds a transaction has in recoverable property with the VPCT. ${ }^{48} \mathrm{He}$ recognised "instructive parallels" as the VPCT "situation exists 'only if and so far as a Court of Equity would in all the circumstances of the case grant specific performance of the contract". ${ }^{49}$ It is the ability of the litigant to compel transfer of the property (land or money) by relying on an equitable remedy (enforcement) and this mere equity arises when the facts which give rise to enforcement occur. ${ }^{50} \mathrm{~A}$ person with an equitable right to compel transfer of property is classically accepted to have an equitable interest in that property; the matter therefore is classifying that equitable interest and when it arose.

\footnotetext{
${ }^{37}$ W.N. Hohfeld, "Fundamental Legal Conceptions as Applied in Judicial Reasoning" (1911) 1 YaleLJ, 710.

${ }^{38}$ Turner (n 4) 584.

${ }^{39}$ R. Nolan, "Understanding the limits of equitable property" (2006) 1 Journal of Equity, 32, and fn 90.

${ }^{40}$ Meagher, Gummow, and Lehane (1975) (n 1) [408] likewise lament: "sadly illustrative of the word-play which in this area passes for analyses".

${ }^{41}$ P.G. Turner (n 4) provides an outline of some of the more obvious duties; A full list of duties is provided in A. Dowling,

“The Vendor's Duty of Care between Contract and Completion" (1995) 26 Cambrian Law Review 33-53.

${ }^{42}$ Harpum, Bridge, and Dixon, Megarry \& Wade: The Law of Real Property (8 ${ }^{\text {th }}$ ed., Sweet \& Maxwell, 2012) 5-028.

${ }^{43}$ Such that an equitable covenant might exist.

${ }^{44}$ E.g. as defined by Lord Wilberforce in National Provincial Bank Ltd v. Ainsworth [1965] AC 1175 (HL); [1965] AC 1175

2 NSWLR 216, 226; See also J. E. Penner "The (True) Nature of a Beneficiary's Equitable Proprietary interest under a trust" (2014) CLJL 27(2) 473-500.

${ }^{45}$ Ainsworth's Case [1965] AC 1175, 1238 per Lord Upjohn; Shiloh Spinners Ltd v. Harding [1973] AC 691 (HL); Latec

Investments Ltd v. Hotel Terrigal Pty. Ltd. (1965) 113 CLR. 265, 277.

${ }^{46}$ Worthington (n 18) $3 \mathrm{fn} 15$.

${ }^{47}$ Torkington v. Magee [1902] 2 KB 427, 429, DC per Channell J; See Halsbury's Laws of England (5th ed., 2010) vol. $13,1$.

${ }^{48}$ R. Chambers, Resulting trusts (Clarendon Press, 1997) 175.

${ }^{49}$ Ibid., 175, citing Bunny Industries Ltd v. F.S.W. Enterprises Pty Ltd [1982] QdR 712, 715, per Connolly J.

${ }^{50}$ Ibid.,
} 
[14] Certain equities and when they arise are particularly important; however, Chambers emphasises a "degree of superficiality in saying that an equitable interest in property (capable of enforcement) arises because of the right to obtain that property", ${ }^{51}$ which is in specie Sir George's argument. While land, money, wine or gold can constitute the subject matter of a trust, so too can invisibles, whether real or personal, ${ }^{52}$ e.g. the benefit of a contract to transfer land, ${ }^{53}$ covenants, ${ }^{54}$ choses in action ${ }^{55}$ and equitable interests. ${ }^{56}$ In Don King Productions Inc. v. Warren (no 1.) it was held that the entire benefit of the contract to assign choses in action was held on trust, ${ }^{57}$ so that Equity would consider it partnership property, ${ }^{58}$ and that equitable interests can comprise the subject matter of the trust. ${ }^{59}$ This means that, while it is outside the bounds of this paper to enter into a protracted definitional discussion of choses in action and mere equities, ${ }^{60}$ the rights arising under a contract to sell property are classified here as an equitable chose in action, personal rights of property enforceable by action and not on physical possession. ${ }^{61}$ To summarise Underbill and Hayton, an equitable interest created by a contract, or an equitable chose in action giving rise to physical recovery by action, can be the subject matter of a trust..$^{62}$ As to the question 'what is held on trust?', a trust which is created by the action of contracting, the answer in the 'Equitable sphere' is: equitable interests (such as the vendor's or purchaser's lien) and mere equities which are electable rights, and primarily two mere choses in action. In the 'legal sphere' (at law) one might conclude that what is held on trust is the legal title or the contract, but we are primarily concerned with what is happening in Equity (although the simpler 'contract' argument may also be valid). These choses respectively allow each party to enforce the judicial sale to transfer or convey or receive the outstanding price. That is, the right of either party to enforce the contract, such that the VPCT is a trust comprised primarily of the chose to enforce the contract, viz the Equity jurisdiction used to enforce a legal obligation. At the end sits the court, able to crystallise the transaction threatened by betrayal of trust, i.e. someone denying their original intention to complete the transaction.

[15] Dr Turner foots his argument on a more generalised policy level, that the VPCT "has the rational justification of protecting the interest that vendor and purchaser each have in the contract being performed", ${ }^{63}$ that the VPCT is about protecting a general performance interest. I argue that what Turner references is the role of specific performance applications, which are derivative (from the contract) and is a misguided assessment not applicable to Equity and the VPCT. What the VPCT is really protecting is another equitable "interest" which stands alone in causing the CT to arise, the mutual equity (interest) of not being betrayed, in terms of the transactional trust you put in the other person. This may be argued on the more general unconscionability principle, but one can point to a specific betrayal, that is, one parties denial of their original transactional intent (to buy or to sell). Should the matter ever get to court (the declaration/enforcement stage), it is self-evident that at some point one party refused to perform (to pay or to convey). Furthermore, on a technical distinction, I conclude that the first trust, the VPCT, dissolves prior to conveyance, as the actual

\footnotetext{
${ }^{51}$ Ibid., 176.

${ }^{52}$ Underhill and Hayton (n 25) [10.1].

${ }^{53}$ Gregory v. Williams (1817) 3 Mer 582; Re Schebsman [1944] Ch 83.

${ }^{54}$ Re Landau [1997] 3 All ER 322, 328.

${ }^{55}$ Kwok Chi Leung Karl v. Commissioner of Estate Duty [1988] 1 WLR 1035, per Lord Oliver 1040;

${ }^{56}$ Simpson v. Norfolk and Norwich University Hospital NHS Trust [2011] EWCA Civ 1149, [2012] 1 All ER. 1423; Lloyd's

v. Harper (1880) 16 Ch D 290; Harmer v. Armstrong [1934] Ch 65; Re Patrick [1891] 1 Ch 82; See Underhill and Hayton [9.84].

57 [2000] Ch 291; [1999] 3 WLR 276 (HC decision upheld [1998] 2 All E.R. 608).

58 Ibid., argued by counsel 309, accepted 343 [44]-[45].

${ }^{59}$ Ibid., [2000] Ch 291, 321; Lightman J in [1998] 2 All E.R. 608, 317 approving Lord Shaw in Lord Strathcona Steamship Co. Ltd v. Dominion Coal. Ltd. [1926] AC 108, 124: "The scope of the trusts recognised in equity is unlimited. There can be a trust of a chattel or of a chose in action, of a right or obligation under an ordinary legal contract, just as much as a trust of land”. See also M. Smith "Equitable Owners Enforcing Legal Rights?" (2008) 124 LQR 519.

${ }^{60}$ W.S. Holdsworth, "History of the Treatment of Choses in Action by the Common Law" (1920) Harvard Law Review 33(8), 1006; E.Q. Keasbey, "Notice of Assignments in Equity” (1910) 19 Yale Law Journal 4, 262-263.

${ }^{61} R$ v. Kohn (1979) 69 Cr App Rep 395, 404, per Geoffrey Lane LJ.

${ }^{62}$ Underhill and Hayton (n 23) [10.2.] citing Kwok Chi Leung Karl v. Commissioner of Estate Duty [1988] 1 WLR 1035, 1040 per Lord Oliver, applied in Re Landau [1997] 3 All ER 322, 328.

${ }^{63}$ Turner (n 4) 604.
} 
obligation to convey stems from a second, bare trust, arising when the contract is completed (e.g. payment made). Therefore, while Turner is correct in arguing that the VPCT is not a singular equitable response but plural responses to a singular event ${ }^{64}$ (this is further emphasised by the decision in Scott v. Southern Pacific), ${ }^{65}$ the equitable interests comprising the trust, mere equities and the choses are also the subject matter of the first VP constructive trust itself. The property/land itself is not held on the VPCT, as the purchaser/beneficiary's right to call for performance of the trust, ${ }^{66}$ the exercise of the chose, leads to specific enforcement of contractual terms, registration of title and conveyance. When the VPCT runs its course, and full payment under the contract of sale is made, under the rule in Saunders $v$. Vautier the CT collapses and a bare trust arises as the vendor maintains no equitable interests. The property proper is held absolutely on trust by the vendor, pending procedural registration and conveyance at HM Land Registry, which officially combines legal and equitable estates in the hands of the purchaser. ${ }^{67}$ The vendor, when constructive trustee, has limited "trustee duties", such that the 'trustee' label is often argued to be a misnomer, ${ }^{68}$ when his trusteeship changes to bare his obligation is primarily statutory, and that is to register and convey. ${ }^{69}$

[16] Professor Waters identifies three of the equities in the transaction and when they arise: ${ }^{70}$

"First, between contract [where I argue conversion occurs] and completion time ${ }^{71}$ [when enforcement is available] when the vendor is interested and obligated as owner [he holds the property on trust and cannot sell to another], secondly, between completion time [enforcement available] and time of actual payment when the vendor has a security interest [lien against the purchaser for money owed], and thirdly, between payment time and actual conveyance when the vendor is a so-called mere trustee."

[17] It follows, as Professors Virgo and Davies argue, that the VPCT is not a constructive trust formed solely on the principle of unconscionability, and therefore this cannot be the unifying factor linking all constructive trusts, something more is required..$^{72}$ The VPCT is likely formed of plural response, to betrayal (as a form of unconscionability) and the courts declaration as to the trust and rights which exist between the parties should they end up enforcing it in court - the latter true of the declaratory nature of all CTs as to the separation of legal and equitable estates. Therefore, the VPCT exists where neither party enforces the trust by declaration (no exercise of the chose), one (a party is an unconscionable malefactor) or both (no unconscionability) of the parties wishes to carry out the contract. It is, as Costigan argues, ${ }^{73}$ a trust imposed on the original intent of either party, to assent the original intent (to carry out the contract), or imposed against latter assent against the original intention (not to pay, or not to convey), against a party unwilling to honour his original obligation. At the most pertinent time, where one party wishes to give proprietary effect to the trust by exercising the chose (should this be possible) and another does not, the trust acts in invitum against the malefactor's unconscionable denial. In the case of the vendor this is denial of the trust

\footnotetext{
${ }^{64}$ Ibid., 606.

65 [2014] UKSC 52 (henceforth Scott).

${ }^{66}$ Saunders v. Vautier (1841) 4 Beav 115; [1841] 49 ER 282.

${ }^{67}$ Form TR1; Land Registration Act 2000 (UK), s 4(1); Nelson v. Greening \& Skyes (n 17) [76]; Akers v Samba Financial Group [2017] UKSC 6, [71] per Lord Neuberger.

${ }^{68}$ Knox v. Gye (1872) LR 5 HL 656, 657-7, per Lord Westbury.

${ }^{69}$ Technically a bare trustee has all the powers of an absolute owner; however, he can avoid using them by conveying the land to the bare beneficiary even against their will: see s 6(2) Trusts of Land and Appointment of Trustees Act 1996 (UK), or other such orders under the Trustee Act 2000 (UK). Vendor bare trustees do not have active duties of management: Jessup v. Lawyers Private Mortgages Ltd [2006] ASC 3, [54].

${ }^{70}$ D.W.M. Waters, The Constructive Trust: The Case for a New Approach in English Law (University of London, Athlone Press, 1964) 91.

${ }^{71}$ Waters means 'completion time' in the sense that both parties can complete the contract; that it is enforceable, the distinction between signing the contract, proving title, and having funds available.

72 P.S. Davies and G. Virgo, Equity \& Trusts (2 ${ }^{\text {nd }}$ ed., Oxford, 2016) 351; see Cobb v Yeomans Row Management [2008] UKHL 55 at [55] per Lord Walker where conscience is defined as "an objective value judgment on behaviour".

${ }^{73}$ Costigan (n 32) 449, a similar argument later espoused by Professor McFarlane (n 75 below). Although Costigan's Trust in Invitum concept was later taken much further and used in the unjust enrichment context. See Beatty v. Guggenheim Exploration Co. (1919) 225 NY 380.
} 
in favour of the purchaser; in the case of the purchaser this is denial of the vendor's lien for the purchase money. The former instance is the two equities which Dr Turner concludes that the VPCT protects, and which I conclude are the subject matter of the trust.

[18] The distinction made here, is, that far from the assertion of Isaacs J that "equitable ownership, as it is called, is always commensurate with the right to relief", ${ }^{74}$ one may not always exercise that right. I advance a deeper exposition which breaks constituent elements of 'equitable ownership' and 'an equity'; both meanings are possible and maybe necessary. Having 'an equity' or such ownership neither determines if it is proprietary nor, if so, its hierarchy as against other rights, and this seems to have been the approach for centuries. The next section will outline how the VPCT operates, and the importance and controversy surrounding equitable conversion or, in simple terminology, the response to the question 'when does the trust arise?' This debate in constructive trust discourse requires a multi-temporal, and a 'backwards-looking' viewpoint similar to that advanced by Professor McFarlane in the estoppel arena. ${ }^{75}$ Simply put, what is the viewpoint when the court looks at back the timeline, categorises the events which have occurred and gives the declaration, and what is the viewpoint at the time of the event? Are we backwards looking in our declaration, or are we forwards-looking?

\section{Equitable Conversion or When the Trust Arises}

[19] What conversion is, and how it relates to the VPCT and to Equity at large is no great mystery; it is defined in the next paragraph. ${ }^{76} \mathrm{It}$ is an old doctrine, if not older than the constructive trust, ${ }^{77}$ yet it has faced centuries of deleterious application. All commentators state that conversion occurs when the contract for sale is capable of specific enforcement. ${ }^{78} \mathrm{I}$ submit that this is incorrect or at least a mass generalisation. The equitable estate converts at the time of the contract, when the equitable obligation arises (the change in the equitable estate), ${ }^{79}$ and this is when the VPCT as a conditional ${ }^{80}$ type of trust arises. ${ }^{81}$ However, whether Equity or the parties give this conversion (the chose/equities) proprietary consequences, or more simply, give effect to this conversion is another matter. ${ }^{82}$ This generalisation error is an uncontroversial proposition, often readily accepted, seemingly supported by reference to the cases, and when unpacked proves taciturn, making conversion and the VPCT appear complex and reserved for luminaires only. Dr Turner considers equitable conversion to be one of the "chief equities" protected by VPCT, ${ }^{83}$ such that a deceased vendor's personal representatives can stand in the position of the vendor to enforce any

\footnotetext{
${ }^{74}$ Trustees Executors and Agency Co Ltd v. Acting FCT (1917) 23 CLR 576, 583. Isaacs J's conclusion stemming from the debate between A.W. Scott and H.F. Stone whether beneficiaries' rights were in rem or in personam.

${ }^{75}$ A. Hudson, Great Debates in Equity and Trusts (Palgrave, 2014) 166; B. McFarlane, "Proprietary Estoppel: The Importance of Looking Back" ch.18 in P.S. Davies and J. Pila (eds.) The Jurisprudence of Lord Hoffmann (Hart, 2015).

${ }^{76}$ J. L Davis, "The Origin of the Doctrine of Equitable Conversion by Contract" (1936) 25 Ky. L.J. 58.

${ }^{77}$ Bubb's Case [1678] EngR 13; (1678) 2 Freem Chy 38; 22 E.R. 1044 (B); Anon (1506) Y.B. 21 Hen. VII f. 41, pl. 66. per Rede $\mathbf{J}$ (a failure to convey case brought in assumpsit).

78 A.J. Oakley, Constructive Trusts ( ${ }^{\text {rd }}$ ed., Sweet \& Maxwell, 1997) 283; Gbolahan Elias, Explaining Constructive Trusts (The Lawbook Exchange Ltd, 1990) 50; David M Wright, The Remedial Constructive Trust (Butterworths, 1998) pt 7.43; Waters (n 70) 126; Malcolm Cope, Constructive Trusts (Law Book Co, Ltd., 1992) 905.

${ }^{79}$ Allen v. IRC (1914) $1 \mathrm{~KB} 327$. Albeit the equitable obligation being distinct from the legal (or contractual) obligation.

${ }^{80}$ Professor Ong describes the VPCT as a "condition precedent trust" Trusts Law in Australia (4 ${ }^{\text {th }}$ ed., Federation, 2012) 616; and the vendor has been described variously over time as a "trustee sub modo" (on condition): Oughtred v IRC [1960] AC 206 (CA), 227 per Radcliff LJ; or "subject to qualification" per Deane J in Kern Corpn Ltd v Walter Reid Trading Pty Ltd (1987) 163 CLR 164, 192.

${ }^{81}$ Meagher, Gummow, and Lehane (1975) (n 29) [329], [3816]; Miliangos v. George Frank (Textiles) Ltd [1976] AC 443, 467; B. McFarlane and C. Mitchell, Hayton and Mitchell: Text, Cases and Materials on the Law of Trusts and Euqitable Remedies (14 ${ }^{\text {th }}$ ed., Sweet \& Maxwell, 2015) 15-016; M. Pawloski, J. Brown, "Contracts for the Sale of Land and Personal Property: the Equitable Interests of the Purchaser" (2011) 20 Nottingham LJ 38; Gordon Hill Trutst Ltd v. Seagall [1941] 2 All ER 379; Lake v Bayliss [1974] 1 WLR 1072

${ }^{82}$ Howard v Miller [1915] AC 318; See also B.A. Battersby, Williams on Title: William's Contract for Sale of Land and Title to Land ( $4^{\text {th }}$ ed., Butterworths, 1975) 712.

${ }^{83}$ Turner (n 4) 595.
} 
obligations. ${ }^{84}$ I submit that, while this is entirely correct, it is but a mere illustration of the doctrine in operation regarding intestacy, the central doctrine itself being far simpler, so much so that it is often overlooked, and this one aforementioned instance is attributed to the whole. That one intestacy operation was of such importance that Maitland devoted a whole lecture to it, introducing the doctrine as "the outcome of the fact that we have two systems of intestate succession ... but for that unfortunate fact we would have no need of this doctrine" 85 - and this instance is technically known as "trust for conversion". ${ }^{6}$ One can be forgiven for thinking that the one operation is indeed the doctrine, although Maitland comments that there are many others. ${ }^{87}$ Professors Cope, Waters and Oakley do not fall into this trap and yet ascribe such complexity to conversion ${ }^{88}$ that Professor Worthington, in that context, concludes that their conception of the doctrine "cannot possibly say anything about whether the vendor or purchaser under an existing contract of sale acquires an equitable proprietary interest by operation of law". ${ }^{89}$ North American commentary on the subject has never been considered in this jurisdiction, for in 1962 the converse problem occurred and it was apparent that the doctrine was only thought of in the instance of VPCT and it was thought fit to remind practitioners to be wary of it arising in the intestacy context that Dr Turner describes..$^{90}$

\section{Defining Conversion and its Operation}

[20] The operation, as opposed to the definition, of conversion must be understood in the context of pre-Judicature Act fusion. It was explained in Fletcher v. Ashburner as the recognition by Courts of Chancery of: ${ }^{1}$

"That change in the nature of property [rights] by which, for certain purposes, real estate is considered as personal, and personal estate as real, and transmissible and descendible as such".

[21] Its use is also central to its definition and is at the core of conceptual Equity. My suggested definition is that: 92

Conversion exists as against the common law, as Equity must recognise and protect beneficial title and equitable interests arising, brought about by change in estates, and looks on agreements regarding those things as actually performed.

[22] Conversion is more than, and is not simply, beneficial title arising and transferring; it is also the reason for the transference, and Equity's recognition that the status of property causing the transference has, in Equity (the jurisdiction), also changed. As Pomeroy explains: "[t]he effect of the conversion is a direct consequence of the [above] principle in question". ${ }^{3}$ Fletcher suggests that conversion considers the nature of property, yet this is not the physical nature of the property to be converted, e.g. the real-estate or personalty, it is the change in/of the equitable property rights, such that that change in the nature of property refers to beneficial title and any other equities arising, the interests in property which only the jurisdiction of Chancery or Equity would recognise.

\footnotetext{
${ }^{84}$ Ibid., 603.

${ }^{85}$ F.W. Maitland, Equity and the Forms of Action at Common Law: Two Courses of Lectures (CUP, 1910) Lecture XVII 216

"Trusts for Conversion", which we no longer have as s 3(1) of the Trusts of Land and Appointment of Trustees Act 1996 (UK) abolished conversion in every instance bar the VPCT.

${ }^{86}$ Ibid., 217.

${ }^{87}$ Ibid., 222, presumably causing so little difficulty that the doctrine, bar its application to intestacy, is of little importance. There are approximately four ways to covert according to Meagher, Gummow, and Lehane (n 29): partnership land, order of the court, contract to sell, settlements and will, 688-690.

${ }^{88}$ See (n 78) above.

${ }^{89}$ Worthington (n 18) 198 fn 58. Although the professor and I disagree on conversion.

${ }^{90}$ M.M. Hermann, "The Doctrine of Equitable Conversion: I, Conversion by Contract" (1962) 12 DePaulLR(1), 1.

${ }^{91}$ There exist two reports of this case with only slight variations in language: Fletcher v. Ashburner (1779) I Bro CC 497; 28 ER 1259; See In Re Richerson (No 1) (Scales v. Heyhoe) [1890] R 753, per Sir Thomas Sewell MR; In Re Richerson (No 2) [1892] 1 Ch 379 per Chitty J.

${ }^{92}$ Conversion is often seen as the result of applying the maxim 'done as ought to be done'. See W.W. Henning, Noy's Maxims, Francis's Maxims (Virginia: T.W. White, 1824) 63 [58], Francis's Max. 13; M.M. Hermann (n 85) 5.

${ }^{93}$ Pomeroy, Equity Jurisprudence (5th ed., 1941) s 371.
} 
Conversion is dependent on the purpose of the conversion. ${ }^{94}$ A leading treatise described the doctrine as subject to "very refined and subtle distinctions" 95 and yet "reducible to some of the most just and simple principles on which ... courts of equity [have] been formed". ${ }^{96}$ Common law courts do not recognise conversion or beneficial title, neither are they applicable 'at Law' prefusion. Merely contracting for the sale of land does not change legal title, the purchaser has no proprietary rights or protection, and may only sue in contract against the vendor. Depending on the system of conveyance title may only pass when it is registered or when a deed is signed, such that full payment by the purchaser prior to conveyance might give only personal rights of recovery. Equity will not allow this to happen and the following occurs:

(i) A "transubstantiation which, in the eye of equity, the property has undergone" 97

(ii) "terra firma is not terra firma" 98 as "money is land and land is money". 99

[23] As to the distinct treatment of the effects of the contract in Chancery and at Law, Lord Eldon explained: 100

"The effect of a contract for purchase is very different at Law and in Equity. At Law the estate remains the estate of the vendor; and the money that of the vendee. It is not so here.

The estate from the sealing of the contract is the real property of the vendee".

[24] The main application of the maxim that equity looks on as done that which ought to be done is the doctrine of conversion ${ }^{101}$ and, like the constructive trust, conversion arises by operation of law and the court's role is to identify and declare its occurrence as between the parties. ${ }^{102}$ The result of the application is that "where land had been directed to be sold, the land was treated in equity as money. Conversely, where a fund of personalty had been directed to be used to purchase land, the fund was treated in equity as land". ${ }^{103}$ The doctrine provides that "the legal and beneficial ownership of the property is separated, with the vendor retaining the legal title to the property, until full performance of the contract". ${ }^{104}$ It is almost impossible to doctrinally separate conversion from VPCT; however, what should be emphasised is that, while conversion takes place when the contract is made, whether or not the conversion is given proprietary consequence turns on factors later to occur or be determined, i.e. by equitable interests and or the exercise of the chose. Most commentary argues that the proprietary consequence (or lack thereof) of conversion depends on whether contractual specific enforcement is possible; ${ }^{105}$ however, in the next section this is not how I conceptualise the temporal issue.

[25] The equitable interests in the property arise due to the contract. Viscount Radcliffe, in denying perennial equitable title, reasoned that due to an event "[e]quity in fact calls into existence and protects equitable rights and interests in property"106 but "only where their recognition has been found to be required in order to give effect to its doctrines". ${ }^{107}$ At the time of contract equitable title is brought into existence and converted from vendor to purchaser, such that the purchaser is beneficially entitled to the property but may not yet call for its enforcement. When the purchaser

\footnotetext{
${ }^{94}$ J.H.J. Leigh and R. Dalzell, A Treatise on the Equitable Doctrine of the Conversion of Property (Joseph Butterworth and Son, 1825) 2.

95 Ibid., 1.

${ }^{96}$ Ibid.,

${ }^{97}$ Ibid., 59.

${ }^{98}$ Hermann (n 80) 7

${ }^{99}$ J.R. Martyn, A. Learmonth, J.E. Gordon, C. Ford, and T. Fletcher, Theobold on Wills $\left(18^{\text {th }}\right.$ ed., Sweet \& Maxwell, 2016) [21-003].

${ }^{100}$ Seaton v. Slade (1802) 7 Ves Jun 265, 273: My italics; note that linguistically the contractual transaction happens in the singular instance "at Law" whereas the equitable transaction occurs throughout "in Equity".

${ }^{101}$ Meagher, Gummow, and Lehane (1975) (n 29) [329]; Theobold on Wills (n 100) [21-003].

${ }^{102}$ See Re Holt's Settlement [1969] 1 Ch. 100, [1968] 1 All ER 470; DHN Food Distributors Ltd v. Tower Hamlets London Borough Council [1976] 3 All ER 462, [1976] 1 WLR 852, CA.

${ }^{103}$ Theobold on Wills (n 100) [21-003].

104 Malcolm Cope, Constructive Trusts (n 78) 905; M. Bridge, L. Gullifer, G. McMeel, and S. Worthington, The Law of Personal Property (1 $1^{\text {st }}$ ed., Sweet \& Maxwell, 2013) 15-063; Worthington (n 18) 188.

${ }^{105}$ Atcherley v. Vernon [1725] ER 75; (1725) $10 \operatorname{Mod} 518$, [93].

${ }^{106}$ Livingston's Case [1965] AC 694, 712.

${ }^{107}$ Ibid.,
} 
and vendor have sufficient equitable interests in the property or fund one or the other exercises his chose, beneficial title is then vested and he may enforce it as against the other. The emphasis that the original Meagher, Gummow, and Lehane places on 'title' is that "a person having full ownership of property [vendor pre-contract] cannot be said to have merely the aggregate of legal and equitable estates; for when united in the one hand these are fused into a whole greater than and different in character from any anterior constituent parts". ${ }^{108}$

[26] This dance of titles happens metaphysically, in the Equity Jurisdiction ethos and not at Law. Often, parties willingly contract, make good title, pay and convey, and neither is aware of the equities or interests they have. This is one type or stage of constructive trust occurring 'in the wilderness' which is often not recognised unless declaration is sought, in which case it is termed 'institutional'. However, if one or the other puts up a 'roadblock' the mere interests become more visible, if exercised turn proprietary, and are enforceable by way of court order/injunction. ${ }^{109}$

[27] It does not, however, follow that, because the purchaser has some or all equitable interests, the contract will be completed or enforced. Lord Walker held that "beneficial ownership [interests] of the land is in a sense split between the seller and buyer on the provisional assumption that specific performance is available and that the contract will in due course be completed...". ${ }^{110}$ The doctrinal principle is "that a valid contract actually changes the ownership of the estate in equity". ${ }^{111}$ The doctrine applies to both land and personalty ${ }^{112}$ so long as specific enforcement is available but the majority of cases concern land as it is the most obvious operation. ${ }^{113}$

[28] It was noted at the start that Equity "often" protects agreements to purchase land arising out of contract, by way of VPCT. Equity is not a set of strict rules with immutable exceptions; the maxim of what ought to be done, and consequentially that of enforcement, cannot "turn the conditional into the absolute, [or] the optional into the obligatory". ${ }^{114}$

[29] The editors of Snell emphasise that the VPCTs underlying policy "is that the rights of those respectively entitled to realty and personalty ought not to depend on the precise moment at which a duty to convert is carried out". ${ }^{115}$ However, I suggest that rights and entitlement turn not on the time of the duty to convert (which I argue occurs at contract) but on whether the duty is recognised by the court as having proprietary consequences (if it is in theory enforceable) or if the parties give it proprietary consequences through the context of the conveyance/transaction (by way of part performance, e.g. payment or planning permission or injunction). The same holds true if something has been done in furtherance of the contract (and this either strengthens the claim or is 'all that is needed'). If, when in dispute and if nothing has been done in furtherance of the contract (e.g. payment, reserving title, etc.), the court finds that the contract was capable of enforcement (by way or theory or deductive reasoning from the facts) then, as Equity considers as done, the conversion is given proprietary consequences (from the date of contract, the conversion). If the court finds the contract, in fact or in theory, incapable of enforcement, then no proprietary consequences can possibly arise.

[30] From the perspective of the court when the parties litigate this transubstantiation can be delineated. Upon the agreement the purchaser acquires beneficial title and the contract converts it to him. One could phrase it technically that he is entitled to the beneficial title but cannot enforce it as against the vendor. If it is proved that money was to be available to perform the agreement (or the contract terms key to performance), either by way of mortgage or cash, then the aforementioned conversion

\footnotetext{
${ }^{108}$ Meagher, Gummow, and Lehane (1975) (n 1) [412], my emphasis.

${ }^{109}$ Sugden (n 20) 223 [73].

${ }^{110}$ Jerome v. Kelly (n 16) [32] per Lord Walker, dicta latter approved by Lord Wilson in Maharaj v Johnson (Trinidad and Tobago) [2015] UKPC 28 at [17] where he noted that "following execution of a contract for the sale of land a vendor retails certain temporary rights in relation to it and the better view is that they are proprietary rather than contractual".

${ }^{111}$ Lysaght v. Edwards (n 17) 507 per Sir George Jessel MR.

112 Oakley Constructive Trusts ( $3^{\text {rd }}$ ed.) (n 78) 282; For a case concerning conversion of personalty, See White v. Nutts (1702)

1 P.Wms 61, 62, per Wright L.J.

113 A. J. Oakley, Parker and Mellows: The Modern Law of Trusts (9 ${ }^{\text {th }}$ ed., Sweet \& Maxwell, 2006) paras 10-335

${ }^{114}$ De Beers Consolidated Mines Ltd v. British South Africa Co [1912] AC 52, 65-66, per Lord Atkinson.

${ }^{115}$ Snell's Equity (33 ${ }^{\text {rd }}$ ed.) (n 14) 6-001.
} 
is given proprietary consequence and the purchaser's money, often in an account somewhere, is deemed converted into beneficial ownership of the land as at the time of contract, before the land has been conveyed. The land is then conveyed now, by way of court order enforcing the VPCT and its proprietary consequences, and any duties owed, by operation of the maxim, flow from conversion.

[31] This occurs not because Equity considers specific enforcement a distinct possibility but because it considers done as ought to be done $e^{116}$ or, from a factual standpoint: what has now been proved as capable of being carried out, is therefore considered as always having been carried out. Thus, by way of "equitable fiction", ${ }^{117}$ land becomes money and money becomes land, ${ }^{118}$ representing a state of affairs in Equity once the mutuality of exchange in Equity occurs. Despite no physical exchange occurring, distinct equitable interests by way of liens arise and secure performance of the obligations and prospectively beneficial title is converted for the purposes of ultimately conveying the estate. ${ }^{119}$ This is distinct from concluding that specific enforcement occurs at conversion. In our context conversion refers to when the equitable estate of land was called into existence and respective entitlement to it changed from the vendor, prior to contract, to that of the purchaser, on contract. ${ }^{120}$

[32] Despite not being beneficially entitled to the estate after contract the vendor retains mere equitable interests in it. Some of these interests are proprietary and arise at different stages, e.g. a lien for outstanding money arising when the contractual situation or bargain is sufficiently certain to be enforceable. Conversely Equity will not allow the purchaser to call for his Saunders v. Vautier21 rights and for the legal title (estate) to be transferred to him whilst he has not paid and the vendor's negative equitable interests are outstanding. The court will not order conveyance without payment as the maxim is mutually applicable: it is considered 'done' that the purchaser has paid the vendor, and now in fact he must pay to effect the judicial sale. The equitable jural reality must in fact be possible such that the court can latterly declare its effect, reality must coincide with maxim, time does not.

[33] At various stages each party has a choice under the contract, which has proprietary consequences as against each other. One might ask why, if it is not the land that is held on trust, this mutual chose and interests? First, because when the VPCT transaction naturally progresses to conveyance (no litigation or court injunction necessary) no outstanding negative equitable interests remain, the vendor has legal title and money, and the purchaser has the full equitable estate and beneficial interests. Therefore, the vendor holds the land on bare inter vivos trust pending title registration by HM Land Registry.122 At that moment the vendor holds land for the benefit of the purchaser absolutely - such that land itself was never held on VPCT but simply the very specific rights associated with it. Secondly, by operation of law, Equity cannot categorise the land as property of the VPCT as, at different times throughout the contract to conveyance, each party can abscond,

\footnotetext{
116 Palatte Shoes Pty. Ltd. v. Krohn (1937) 58 CLR 1, [16]; See Banks v. Sutton (1732) 2 P.Wms, 700,715 for an original discussion of the maxim.

${ }^{117}$ As opposed to legal fiction, of which this is a mere nomenclature distinction pre-judicature fusion; see Lon. L. Fuller, Legal Fictions (Stanford University, 1967) 33; Shaw v. Foster (1872) LR 5 HL 321, 357 per Lord Hatherley LC; Wall v. Bright (1820) 37 ER 456 (Ch) 459, [503] per Sir Thomas Plumer MR.

${ }^{118}$ Lechmere v. Earl of Carlisle (1733) 3 P Wms 211, 215 per Sir Joseph Jekyll MR.

${ }_{119}$ Chandler v. Pocock (1880) 15 ChD 419, 496 per Sir George Jessel MR, (affirmed (1881) 16 ChD 648). See C. Rotherham, Proprietary Remedies in Context: A Study in the Judicial Redistribution of Property Rights (Oxford: Hart, 2004), 45 where he concludes that the effect of conversion is to give the maxim effect; Fletcher v. Ashburner [1779] 28 ER 159. [499] per Sir Thomas Sewell MR; See In Re Richerson (No 1) (Scales v. Heyhoe) [1890] R 753; [1892] 1 Ch 379 per Chitty J.

${ }^{120}$ Technically in a simple example prior to the contract nothing would have called the equitable estate into existence; this is known as the rule in Selby v. Alston (1797) Ves. 339, 342, per Arden MR; D. Fox, "Relativity of Title at Law and in Equity" (2006) CLJ 65(2) 330, 333. G. Spence, The Equitable Jurisdiction of the Court of Chancery, Vol I (V. \& R. Stevens and G.S. Norton, London, 1846) 509.

121 (n 66).

122 Form TR1 and the time delay during this period; Oakley (n 73) 293; M. Cope, Constructive Trusts (Law Book Co, Ltd., 1992) 904; Modern application is found in: McWilliam v. McWilliams Wines Ply Ltd (1964) 114 C.L.R. 656 , 660 per McTiernan and Taylor JJ.; Bunny Industries Ltd v. F.S. W. Enterprises Pty Ltd [1982] Qd R. 712; Historical application in: Rose v. Watson (1864) 10 H.L.C. 678 per Lord Cranworth; Shaw v. Foster (1872) L.R. 5 H.L. 321, 349 per Lord O'Hagan.
} 
and this may or may not have consequences in Equity. If one party walks away before the contract is enforceable then beneficial title is extinguished or reconverted back to the vendor because their chose was not exercised. Should the converse occur, as in all constructive trusts the court acts to guard against the intention of the malefactor, whose conduct has a taint of illegality/unconscionability. At the core of the VPCT is this mere chose, and the point at which it can be exercised gives prospective proprietary consequences in Equity to the common-law contract.

\section{Specific Enforcement by way of Injunction or Order}

[34] When a contract is susceptible to specific enforcement ${ }^{123}$ Equity can, if asked, insist on its performance by compelling upon the conscience of the party performance of their bargainedobligations ${ }^{124}$ and ordering a mandatory injunction. ${ }^{125}$ The availability of this enforcement remedy has basic requirements ${ }^{126}$ such that damages are an inadequate remedy. ${ }^{127}$ This is often because the subject is land and English law deems land to be unique, ${ }^{128}$ or if personal chattels or shares in a private company that they are unique, ${ }^{129}$ and because the claimant is willing to, or has performed, their obligation, ${ }^{130}$ and because the contract cannot be vitiated. ${ }^{131}$ This justifies proprietary consequences. The scope of the remedy and what is deemed to be specifically enforceable is unlimited. ${ }^{132}$ It is in theory, but not often in practice, a discretionary remedy, ${ }^{133}$ such that title to property can be converted, the contract is susceptible to specific enforcement, and Equity can decline.

[35] It was stated earlier that "The equitable estate converts at the time of the contract when the obligation arises, and this is when the conditional type of trust arises, the VPCT. Whether Equity, or the parties, gives this conversion (the chose/equities) proprietary consequences is another matter". This conclusion stems in part from the essential requirement of specific enforcement of the obligations. Much of the confusion in VPCT case law stems from disagreement over whether the vendor becomes a trustee (and thus whether the trust arises) upon entering into the contract or upon payment of the purchase money by the purchaser. These questions are in effect asking when beneficial entitlement arises and, as earlier concluded, a form of beneficial entitlement, but notably conditional on proprietary consequence, arises on contract. As the Irish Law Reform Commission explain, this conditional-conclusion "is subject to the qualification that the contract must be one of which a court would grant specific performance", 134 such that while for most purposes and in most cases "...it is tacitly assumed that

\footnotetext{
${ }^{123}$ Other types of enforcement orders exist unrelated to the defendant's person such as sequestration, appointment of a receiver, and execution of a document by a court officer.

${ }^{124}$ Hugh Beale QC, Chitty on Contracts (32 ${ }^{\text {nd }}$ ed., Sweet \& Maxwell, 2015) 27-004.

${ }^{125}$ See CPR 40; HM Courts \& Tribunals Service, The Commercial Court Guide, (10 ${ }^{\text {th }}$ ed., Crown Copyright, 2017) D.19; V. Chapman, L. Counsell, Chancery Practice and Procedure (Jordans, 2001) 6.29; Co-operative Insurance Society Ltd. v. Argyll Stores (Holdings) Ltd [1998] AC 1: as opposed to a prohibitory injunction.

${ }^{126}$ Haywood v. Cope (1858) 25 Beav 140, 151.

${ }^{127}$ Harnett v. Yielding (1805) 2 Sch. \& Lef. 549, 553; Lawrence v. Fen Tigers Ltd. [2014] UKSC 13, [2014] 2 ALL ER 622, [158].

${ }^{128}$ Meng Long Development Pte Ltd v. Jip Hong Trading Co Pte Ltd. [1985] AC 511. This is the position in English law. Canadian law differs. See Sopinka J. in Semelhago v. Paramadevan [1996] 2 SCR 415 (SCC) which Robert Chambers criticises in "The Importance of Specific Performance", in S. Degeling and J. Edelman (eds.), Equity in Commercial Law (NSW, Lawbook Company, 2004) 431, because land is intrinsically non-substitutable.

${ }^{129}$ Pusey v. Pusey (1684) 1 Vern 273; (1684) 2 ER 465, concerning an "heir loome" ancestral horn; Falcke v. Gray (1859) 4 Drewry 651; (1859) 62 ER 250, concerning china jars.

${ }^{130}$ Oakley Constructive Trusts ( $3^{\text {rd }}$ ed.,) (n 78) 277.

${ }^{131}$ While the CT requires, and indeed operates, on the presumption that no common-law formalities are required, for a VPCT to arise the contract must be valid. Issues of capacity, mistake, misrepresentation, and undue influence can be raised as vitiating factors such that VPCT could not arise. This is especially pertinent as the VPCT is often argued at summary judgment.

${ }^{132}$ D. Bean, A. Burns, and I. Parry, Injunctions (12 ${ }^{\text {th }}$ ed., Sweet \& Maxwell, 2015) [1-14].

${ }^{133}$ See the SCC; Semelhago v. Paramadevan [1996] 2 SCR 415, 136 DLR (4th); emphasised by R. Chambers, "The Importance of Specific Performance" in Equity in Commercial Law (n 18) 434-48.

134 The Law Reform Commission, "Report on Land Law and Conveyancing Law: (3) The Passing of Risk from Vendor to Purchaser" (Dublin LRC39-1991) 2.1: Citing Harnett v Yielding (1805) 2 Sch \& Lef 549. The Commission concludes that the 'at contract' position is the law in Ireland.
} 
the contract would in a Court of Equity be enforced specifically", ${ }_{135}$ "specific performance is regarded as a sine qua non' 136 as if Equity lacked the ability to enforce the contract there could be no proprietary consequences. There is, however, an air of falsity in always assuming, even with land, that enforcement is available, for example, if the title proves tainted then enforcement is, and never was, possible. Relevant here is the level of the judge's inquiry into the extent to which the contract could be performed at the relevant time, often this is rather lax.

[36] The argument advanced here is that as the constructive trust which arises at contract lacks proprietary consequences at that time, and is conditional, there is no falsity in later finding that no proprietary consequences can be given because enforcement is unavailable. It is illogical to conclude that enforcement must be available if the trust is to subsist, ${ }^{137}$ and then to also conclude that the trust arose at contract, if the conditions to prove/create enforcement could not arise until much later (the future) nor could be analysed until then.

[37] Specific enforcement will only be granted if both purchaser and vendor are capable of performing their bargain. ${ }^{138}$ The obligations are often contract-specific but, when generalised, they are 'the ability to pay' and 'the ability to make good title' - at that point the contract is deemed to be enforceable. Enforcement in the context of VPCT has a broader meaning than the strict sense of enforcing the contract and its terms: ${ }^{139}$

"Rather it encompasses all of those remedies available to the purchaser in equity to protect the interest which he has acquired under the contract. In appropriate cases it will include other remedies such as relief by way of injunction, as well as specific performance in the strict sense".

[38] Equity's constructive trust jurisdiction arises on the making of a valid contract intending to transfer property; where denial of the original intention would be unconscionable. ${ }^{140}$ As to the resulting proprietary consequences, the distinction between an action for specific enforcement at Law and in Equity is that the former can only enforce monetary obligations whereas the latter is "heavyhanded"141 and attaches ${ }^{142}$ to the person in breach giving "the other party a right at his election either to insist on the actual performance of the contract, or to obtain satisfaction for the nonperformance". ${ }^{143}$ Matters in Chancery are fact-orientated, it is primarily a court of conscience, and yet the doctrines of Equity and the maxim which underpin specific enforcement at first appear to militate against this. Apportioning property based on a thorough analysis of facts, is not, as some would argue, evidence of unfettered discretion in Chancery or remedialism.

[39] Either party may wish to protect their interest(s) in the land or the fund prior to a breach. ${ }^{144}$ The action can be used in anticipation, ${ }^{145}$ where the court can order the contract to be performed before the agreed date if repudiation/frustration is foreseeable ${ }^{146}$ or even for remedial work to be done

${ }^{135}$ Central Trust and Safe Deposit Co v. Snider (1876) 2 ChD 449, 510.

136 M.P. Thompson, "Must a Purchaser Buy a Charred Ruin?" (1984) Conv 43, 44.

137 Plews v. Samuel [1904] 1 Ch 464; M.P. Thompson, "Must a Purchaser Buy a Charred Ruin?" (1984) Conv 43, 45.

${ }^{138}$ Oxford v. Provand (1868) LR 2 PC 136 (PC China) 156.

${ }^{139}$ Stern v. McArther (1988) 165 CLR 489, 522 per Deane and Dawson JJ.

${ }_{140}$ Chitty on Contracts (n 127) 27-003; Westdeutsche Landesbank (n 5) 714-715.

${ }^{141}$ Co-operative Insurance Society Ltd v. Argyll Stores (Holdings) Ltd [1998] AC 1, 12.

${ }^{142}$ Enfield LBC v. Mahoney [1983] 1 WLR 749, in which the defendant was imprisoned until he complied with the order. See sch.1 pt.I art.5(1)(b) of the Human Rights Act 1998 (UK) which permits such imprisonment (e.g. for civil contempt). CPR Part 81 sets out the notice requirements in applications (either committal, contempt of court, sequestration, breach of judgment or undertaking) for contempt liability arising from refusal to carry out specific performance or directions of constructive trusteeship. For the applicability of CPR to constructive trusts, See NABB Brothers Ltd v. Lloyds Bank International (Guernsey) Ltd [2005] EWHC 405 (Ch) per Lawrence Collins J.

${ }^{143}$ The monetary equivalent of what he would have had should the contract have been performed, quite different to an assessment of damages from loss. Fry, Specific Performance $\left(6^{\text {th }}\right.$ ed., Sweet \& Maxwell 1921) 21; See Patel v. Mirza [2016] 3 WLR 399, [160] per Lord Neuberger.

${ }^{144}$ Roy v. Kloepfer Wholesale Hardware and Automotive Co. [1951] 3 DLR 122.

${ }^{145}$ Hasham v. Zenab [1960] AC 316, 329-320, in which the Privy Council allowed enforcement of the contract as soon as conversion operated, and the plaintiff did not have to wait until the end of the conveyance period for the breach to occur so long as he could show justification for intervention.

${ }^{146}$ Hasham v. Zenab [1960] AC 316, 325. 
ensuring performance on the appropriate date, ${ }^{147}$ even dictating the method of performance, such that the rule that courts avoid supervisory roles in enforcement appears relaxed if the injunction stems from a foreseeable breach of trust. ${ }^{148}$

[40] In this context the widened scope of enforcement suggests that Courts seek to guard against intentional abandonment by finding a VPCT, thus reflecting a varied unconscionability principle evident in this CT. This protects both the converted title, if the agreement is far enough along the continuum to warrant proprietary consequences (the availability of enforcement), and each party's interests in money paid or due.

\section{Specific Enforcement as Discretionary Element?}

[41] Denial of specific performance is fatal to a VPCT claim as the purchaser will not receive the unique and irreplaceable property they have contracted to purchase, be it land or rare personalty. They may receive equitable damages or compensation ${ }^{149}$ but damages can never adequately compensate for the denial of unique equitable proprietary interests, and denial will be rare, one may as well sue in contract. A court will only decline to uphold an equitable interest, estate or entitlement in the very rare instance where it is more unconscionable/detrimental to uphold the beneficial interest than to protect it. ${ }^{150}$ In the case of post-VPCT property now held on absolute bare trust, where the purchaser has paid and is entitled to the equitable estate (is absolutely interested in it), ${ }^{151}$ denial is almost inconceivable except in restricted circumstances.

[42] Enforcement has been denied where the result would be voidable, illegal ${ }^{152}$ or perhaps contrary to public policy. ${ }^{153}$ Specific performance was denied in Patel v. Alit54 when the vendor became ill155 and the case is often used as authority for the discretionary nature of specific performance; however, in fact the plaintiff's claim failed due to laches. ${ }^{156}$ The case holds that "in the ordinary case of a sale of land or buildings [or rare personalty] the court normally grants [specific performance] as of course and withholds it only on proof of special facts"; 157 such facts would ostensibly be none other than those settled instances where courts already decline enforcement. ${ }^{158}$ Professor Birks describes the right to enforcement as "weakly discretionary", so much so that as we know the instances when performance will be denied it is proper to speak of a 'right' to enforcement. ${ }^{159}$ In the context of VPCT commentators often find difficulties in reconciling this discretionary aspect of enforcement but the practice of the law is such that where compensatory

\footnotetext{
${ }^{147}$ Airport Industrial GP Ltd v. Heathrow Airport Ltd., AP16 [2015] EWHC 3753 (Ch), [113] per Morgan J.

148 Ibid., [144].

${ }^{149}$ See Simone Degeling and Jason NE Varuhas (eds.) Equitable Compensation and Disgorgement of Profit (Hart, 2017) introduction.

${ }^{150}$ Although I do not mean this in the unjust enrichment terminology. This was the approach taken by the High Court of Australia in Muschinski v. Dodds (1985) 60 ALJR 52 regarding the retention of property when the joint venture collapsed, per Deane J, 96; See A. Mason "Declarations, Injunctions and Constructive Trusts: Divergent Developments in England and Australia" (1980) 11 Uni Qld LJ 121, 129.

${ }^{151}$ Re Transphere Pty Ltd. (1986) 5 NSWLR 309, 311 per McLelland J; See the judgment of Lord Millett (in dissent on a different point) in Twinsectra Ltd. v. Yardley \& Ors [2002] UKHL 12, [89]-[91] although on the Quistclose trust he took the approach identifying the location of the equitable estate. He approved similar analysis by Gibson J in Carreras Rothman Ltd. v. Freeman Matthews Treasure Ltd. [1985] Ch 207, 233; and Sir Robert Megarry V.-C. in Re Northern Developments (Holdings) Ltd. (unreported), 6 October 1978 (not to be confused with [1977] 1 ALL ER 747).

${ }^{152}$ Patel v. Mirza [2016] 3 WLR 399, [267] per Lord Sumption, where the contract was a result of insider trading; Such as the swaps contract in Westdeutsche Landesbank (n 5). See Patel v. Mirza [159]-[160].

153 A. Burrows, Restatement of the English Law of Contract (OUP, 2016) 225.

${ }^{154}$ Patel v. Ali [1984] Ch 283 per Goulding J.

${ }^{155}$ She was pregnant, had cancer, her leg was amputated, her husband who organised the sale was in prison, and she spoke no English.

156 A. Burrows "We Do This At Common Law but That in Equity" (2002) QJLS 22(1)1, fn 67, categorises the agreement as void due to claimants "acquiescence" (allowing the Ali's to remain in the property for four years after the contract by not enforcing it.). Acquiescence to the to the defendant's conduct, and or, an altered position, being elements of the defence; see Lindsay Petroleum Co v. Hurd (1874) LR 5 PC 221.

157 Patel v. Ali, 288.

${ }^{158}$ Peter Watts, "Constructive Trusts and Insolvency" (2009) 3 Journal of Equity, 256.

${ }^{159}$ Peter Birks, Can Sense be Made of the Remedial Constructive Trust (Nedlands, UWA, 1991), 10.
} 
damages are inadequate, where the claimant has proprietary interests in the property, and where it is not the fault of the claimant, ${ }^{160}$ the court will enforce.

[43] Furthermore, enforcement is not limited to land alone, as long as goods are unique they too can avail themselves of it, and the law above also applies to VPCT of such personalty. That said, whilst land is or is deemed to be unique, the exclusivity of goods is essentially a normative inquiry and remedies are unpredictable and open to criticism, ${ }^{161}$ with courts now recognising a variegated standard of 'commercial uniqueness', ordering enforcement if the property is commercial and not readily obtainable. ${ }^{162}$

\section{When is the VPCT given Proprietary Consequences?}

[44] In Jerome v. Kelley the House of Lords held that "if the buyer proceeds to completion the equitable interest can be viewed as passing to the buyer in stages, as title is made and accepted and as the purchase price is paid in full". ${ }^{163}$ This dictum aligns with the theory advanced here but is stated on a more general level. Dr Turner's thesis emphasises the role of the purchaser's interest compounding in "stages", "strengthening the protection of the performance interest". ${ }^{164}$ Where the contract for sale is enforceable the question remains as to when the courts will recognise the proprietary consequences of the conversion. Although it should be noted that courts and commentary phrase this as when does conversion occur? and treat the two as simultaneous, whereas I delineate conversion and proprietary consequences.

[45] Commentators argue that full conversion, that is transfer of the equitable estate ${ }^{165}$ from vendor to purchaser, occurs at the time the contract is capable of specific enforcement, ${ }^{166}$ i.e. at a variegated point after the contract has been made when everything is done that ought to be done. ${ }^{167}$ They argue that if the trust is eventually enforced, recognised by declaration, then conversion is backdated or 'deemed' to exist as at the time of the contract, so that the vendor is then under trustee obligations during the no-liability lacuna period between contract and conversion (the point where the transaction was susceptible to enforcement). ${ }^{168}$ This retrospectivity has an air of falsity about it, ${ }^{169}$ especially as both conversion and constructive trust occur by operation of Equity. Deeming cannot seemingly be justified other than on the grounds that it would be inequitable for the vendor not to be under obligations, and potentially damage the property between contract and conversion/enforcement. ${ }^{170} \mathrm{~A}$ better approach recognises that conversion occurs as at the date of contract and it is up to the parties to give their agreement proprietary effect. If they do so then duties flow forth from the date of contract/conversion. This recognises the mutual interest each has in preforming the transaction; the transactional equity of their chose. If the agreement is not

\footnotetext{
${ }^{160}$ G. Virgo, The Principles of the Law of Restitution ( $3^{\text {rd }}$ ed., Oxford, 2016) 483-4; AG v. Blake [2000] UKHL 45; Surry CC v. Bredero Homes Ltd [1993] 1 WLR 1361, 1371; Co-operative Insurance Society Ltd v. Argyle Stores (Holdings) Ltd [1998] AC 1, 12. I doubt that Chancery refuses due to supervision in the context of trusts, as that is the courts primary role.

161 J. Singer, Property Law: Rules, Policies and Practices (2 $2^{\text {nd }}$ ed., Aspen Law \& Business, 1997) 939; R. Cunningham, W. Stoebuck, and D. Whitman, The Law of Property (West Publishing Co., 1993) 743.

${ }^{162}$ Chitty on Contracts (n 127) pts 27-013.

163 Jerome v. Kelly (n 16) [29].

164 Tuner (n 4) 584.

165 Although commentators and judges vary in their use of beneficial title vs. equitable estate in reference to the same and differing concepts. Estate is proper here as there are two estates in land: E.L.G. Tyler, N.E. Palmer, Crossley Vaines' Personal Property (5th ed., London, Butterworths, 1973) 6; Uniform terminology in Equity would be helpful, and linguistic indeterminacy is a bar to doctrinal cogency: Bix Law, Language, and Legal Determinacy (Clarendon, 1995) 47; T.A.O Endicott, Vagueness in Law (OUP, 2000) 9.

${ }_{166}$ Oakley Constructive Trusts ( $3^{\text {rd }}$ ed.) (n 78) 283; Gbolahan Elias (n 78) 50; David M Wright (n 78) pt 7.43; Waters (n 70) 126.

${ }^{167}$ Worthington (n 18) 188, arguing that the purchaser will only become the equitable owner of the vendor's legal property if the vendor is under a mandatory, unconditional obligation to transfer identified property. I think this would only occur at the bare trust stage, making the VPCT an irrelevancy. On the argument advanced here proprietary consequences in Equity can occur much earlier.

${ }^{168}$ Underhill and Hayton (n 25) pt 31.5; Oakley Constructive Trusts ( $3^{\text {rd }}$ ed.) (n 78) 282.

${ }^{169}$ P.H. Pettit, "Conversion under a Contract for the Sale of Land" (1960) 24 Conv (NS) 47; Waters (n 62) 76-87.

${ }^{170}$ Underhill and Hayton (n 25) pt 31.6.
} 
given proprietary effect then, like the trust itself, the respective constructive (and limited) 'trust' duties "dissolve" and only personal contractual rights and remedies remain. ${ }^{171}$

[46] Due to the unique nature of land conveyancing and registration the contract does not normally become technically enforceable until sometime after the parties have entered into it (and on contracting converted the beneficial title pending possible proprietary consequence). There is often a period where gazumping is perfectly acceptable. Parties may have to seek advice, gain mortgage approval, prove title, undertake remedial work or simply investigate whether performance is indeed possible. ${ }^{172}$ The maxim that equity considers done, and thus the conveyance is treated as done before it actually is, does not work if it is not possible to perform the contract or if one party does not actually have the money to pay for the property. At the contract stage the purchaser has a mere chose in action in performance of the contract, and has mere equities in the property (interests which are conditional on enforcement being available), but their equitable estate and beneficial interests are not absolute; they are mere equities until the vendor's good title and the purchaser's own ability to pay is known, this will often not occur for some time. Therefore, the trust (albeit constructive) is the perfect vehicle for protecting these transactional interests.

[47] There are five identifiable stages when the contract could be capable of enforcement:

a. The price has been paid in full but conveyance/registration ${ }^{173}$ is not complete;

b. The deposit or some amount has been paid but the property is not conveyed/registered (a vendor's lien for the outstanding purchase amount); 174

c. The contract has been agreed but no payment has been made;

d. The property has been conveyed/registered but the price has not been paid (a vendor's lien for the purchase price); and/or

e. There is a valid contract capable of specific performance but the contract is not completed by mutual agreement.

[48] All these stages are overshadowed by the reality that payment is distinct and often conflated with the validity of the agreement. Although it often serves as sufficient proof, specific enforcement is not contingent on money actually being paid but on it being available or able to be paid.

[49] At Stage (a) if a purchaser makes immediate full payment for property, to be conveyed in the future, no VPCT arises, only bare inter vivos trust, as the purchaser becomes the absolute beneficiary and can invoke their Saunders $v$. Vautier ${ }^{175}$ rights, collapsing the constructive trust and demanding transfer of legal title from the trustee vendor. They may do so under the Trustee Acts ${ }^{176}$ however the usual route is to sue for specific performance by way of summary judgment. ${ }^{177}$

[50] As to the bare trust, if the vendor can make good their title as per the contract, or the purchaser is willing to accept something less than good title, then the contract is enforceable. ${ }^{178}$ The next stage is often full payment of the purchase price. From this perspective, the operation of the VPCT can be further delineated. Completion of the contract, e.g. payment and registering title, can be separated from the formalities of conveyance and title registration. Equity considers the contract complete despite the outstanding technical obligations to formally register the land at Law. Therefore, at stage (a), the VPCT is performed when the contract is made (conversion), and a

\footnotetext{
${ }^{171}$ Akers $v$ Samba (n 67) [62]-[63] Lord Neuberger refers to this as the colloquial phrasing.

${ }^{172}$ Cope (n 78) 906.

173 This paper uses land as the obvious example; however, registration applies to most private shares, and often on delivery for rare personalty.

${ }^{174}$ J. Hardingham, "Equitable Liens for the Recovery of Purchase Money" (1985) 15 MULR 65, 67-68.

175 (n 66).

${ }^{176}$ Re Ralli's WT [1964] 2 WLR 144; Trustee Act 1925 (UK) ss 50, 57-59, s 68(17) providing that "the expressions 'trust' and 'trustee' extend to implied and constructive trusts"; Trusts of Land and Appointment of Trustees Act 1996 (UK), s 14(a)-(b).

${ }^{177}$ See V. Chapman and L. Counsell, Chancery Practice and Procedure (Jordans, 2001) 6.3: whereby the matter can be raised by part 8 proceedings, and "relief consequential upon a finding that would prevent specific performance can be made". See Englewood Properties v. Patel [2005] 1 WLR 1961, a case heard in the first instance by Master Moncaster granting summary judgment for specific performance.

${ }_{178}$ Re Thomas (1886) 34 Ch D 166; Broome v. Monck (1805) 10 Ves 597; Plews v. Samuel [1904] 1 Ch 464.
} 
bare trust arises as an equitable response to this completion, with the former vendor now holding legal title absolutely on trust ${ }^{179}$ and the vendor's trusteeship being no longer 'qualified'.

[51] Often payment is the most discernible factor in identifying conversion and is all that is required for factual pleadings. Many historical cases hold the vendor as the trustee upon payment, ${ }^{180}$ and some commentators argue that there must indeed be some payment for conversion to occur. ${ }^{181}$ In practice, as the criterion of enforcement requires that payment of the agreed price is possible, it is unsurprising to find, in precedents where the price was in fact paid (thus proving the possibility), dicta holding that this was when conversion occurred as a matter of simple expediency, if not misleading. Megarry $\approx W$ ade are correct in their explanation that "the purchaser becomes the owner in the eyes of equity from the date of the contract. It is, therefore, irrelevant that the date for completion (when the purchaser may pay the price and take possession of the land) has not arrived". ${ }^{182}$ However, this is stated without qualification as to when proprietary consequences occur it, like Sir George's definition, is too general.

[52] The VPCT is often overlooked by experts in the field. Sir Nicholas Browne-Wilkinson in a lecture on constructive trusts expressed the idea that "manifestly there is much unconscionable behaviour which does not give rise to a remedy. For example the [person] who has agreed to sell a house subject to a contract and then at the last moment sells at a high price to another", ${ }^{183}$ seemingly omitting a species of a genus for which he would become famed. ${ }^{184}$

[53] Salient in Jerome was the finding that the "contract was unconditional but [the purchaser] could rescind it at any time if outline planning permission for specified purposes was refused" (the seeming antithesis of unconditional). ${ }^{185}$ Nevertheless the importance of this finding was that while there was a binding contract, such that the vendor was under trustee obligations not to sell to anyone else, 186 and on my analysis conversion occurred, the court would only consider that conversion had occurred, and the contract was capable of specific performance, ${ }^{187}$ when planning permission was granted. ${ }^{188}$ These two positions can be reconciled somewhat by recognising that at the date of contract mere equities and the primary chose in action arose but these interests could only be given proprietary consequences, that is the chose exercised and thus mere equities enforced, when planning permission was given. As I argued earlier, the area suffers from much linguistic overlap.

[54] Therefore, although unusual, it seems possible for a party to resist enforcement despite full payment being made by showing that something wholly material has not been done (i.e. the lack of planning permission). The maxim/specific enforcement is then inapplicable as something has impeded the chose being exercised. This illustrates that payment is not the key criterion for proprietary consequences.

[55] In a similar vein stage (a), regarding unique personalty, is not so unusual in that full payment is often made before delivery. If the personalty is such that specific enforcement is available then a VPCT (often in this context known merely as a CT) will arise over the goods. ${ }^{189}$ This position is

${ }^{179}$ Bridges v. Mees [1957] CH 475, 485; Lloyds Bank PLC v. Carrick (1996) 28 HLR 707, 714

180 Shaw v. Foster (1872) LR 5 HL 321, 357 per Lord Hatherley LC; approving Wall v. Bright (1820) 37 ER 456 (Ch) 459 , [500] per Sir Thomas Plumer MR.

${ }^{181}$ Megarry \& Wade (n 42) [15-056]: "the purchaser does become in some sense the owner of the property in equity to the extent that he pays all or part of the price (or furnishes other consideration)".

${ }^{182}$ Ibid., 15-052. Although See above for a contradictory statement in the same chapter.

${ }^{183}$ Sir Nicholas Browne-Wilkinson (n 7) 7.

${ }^{184}$ Indeed, while sitting as HCJ Sir Nicholas enforced a VPCT in Prosper Homes Ltd v. Hambros Bank Executor \& Trustee Co Ltd (1980) 39 P\&CR 395, and again as Vice-Chancellor in Bechal and Another v. Kitsford Holdings Ltd [1989] 1 WLR 105 , although neither raised any interesting issue of law.

185 Jerome v. Kelly (16) [18], [36] Lord Walker describes the contract as "although unconditional in legal terms the contract was attended by many commercial uncertainties centring on the application for planning permission". ${ }^{186}$ Ibid., [37].

${ }^{187}$ Similarly, Sir George emphasised that the "moment you have a valid contract for sale the vendor becomes in equity a trustee for the purchaser of the estate sold": Lysaght v. Edwards (n 17) 506.

188 Jerome v. Kelley (n 16) [37].

${ }^{189}$ And the issues of the unidentifiable fungible mass in Re Goldcorp [1994] UKPC 3, and Re Wait [1927] 1 Ch 606, 630 Re

London Wine, will not present. 
mirrored and somewhat overtaken by statute, ${ }^{190}$ whereby property in unascertained goods ${ }^{191}$ (not unique) will not pass until the buyer has possession ${ }^{192}$ but property in specific ascertained goods ${ }^{193}$ (unique) will pass without possession when it is intended to. ${ }^{194}$

[56] One might pause for a moment and note that, however ill-advised, if a person enters into an oral contract for land and makes immediate full payment with conveyance at some date in the future, whilst this would fall foul of the writing requirements, ${ }^{195}$ section 53(2) of the Law of Property Act 1925 would then act as an exception and two trusts would exist. A constructive trust would exist to ensure that no unconscionable benefit due to lack of formalities is taken by the trustee of the final, sub-bare trust. ${ }^{196}$ Similarly, stages (b) and (c) turn on whether there is a valid contract for sale. The judgment of Sir George Jessel MR ${ }^{197}$ is still the leading dictum concerning these stages. In the next part this is further defined with examples by identifying when the lien and chose arise. He held the following: ${ }^{198}$

i. "[T]he moment you have a valid contract for sale the vendor becomes in equity a trustee for the purchaser of the estate sold..." [the estate is converted, conversion occurs].

ii. "Valid contract' means in every case a contract sufficient in form and substance, so that there is no ground whatever for setting it aside as between the vendor and purchaser - a contract binding on both parties."

iii. However: "[a]s regards real estate[...]another element of validity is required. The vendor must be in a position to make a title according to the contract, and the contract will not be a valid contract unless he has either made out his title according to the contract or the purchaser has accepted the title". [This is when the chose is exercisable, the contract enforceable, and the vendor's lien arises.]

iv. "[T]he moment [the purchaser] has accepted the title, the contract is fully binding on the vendor". [Bare trust stage.]

V. " $\Pi \mathrm{f}$ the title is accepted in the lifetime of the vendor, and there is no reason for setting aside the contract, ${ }^{199}$ then, although the purchase-money is unpaid, the contract is valid and binding."

\section{Equitable Liens as an Interest under VPCT}

[57] Liens arise by operation of law whenever there is an obligation to pay or hand over an asset ${ }^{200}$ and, even should the court find the contract unenforceable, Equity's maxim still imposes a personal obligation on the vendor as he ought to convey or return the price. ${ }^{201}$ Providing enforceability is met the vendor's lien secures payment, ranking him a secured creditor in insolvency. ${ }^{202}$ The equitable lien does not depend on contract or possession ${ }^{203}$ in particular; it arises as "security for money justly due" and

\footnotetext{
190 The Sale of Goods Act 1979 (UK), s 16, provides that in contracts for the sale of unascertained goods property will not pass to the buyer until the goods are ascertained.

${ }^{191}$ Where specific performance would not generally be available.

192 With the proviso that if the goods are unascertained because they are bulk (as opposed to generic) then the Sale of Goods (Amendment) Act 1995 (UK), s 2(a) applies, permitting specific performance if the contract was for a percentage or fraction of the bulk agreed in the contract.

${ }_{193}^{19}$ TTK LIG Ltd [2011] EWCA Civ 1170; [2012] 1 ALL ER (Comm.) 429, [89]; Cohen v. Roche [1927] 1 KB 169, 181.

${ }^{194}$ Sale of Goods Act 1979 (UK), s 52, s 19. See the Consumer Rights Act 2015 (UK), s 19.

${ }^{195}$ Law of Property (Miscellaneous Provisions) Act 1989 (UK), s 2(5).

${ }_{196}$ Westdeutsche Landesbank (n 5). See Neville v. Wilson [1997] Ch. 144; [1966] 3 WLR 460 (CA), 158.

${ }^{197}$ Lysaght v. Edwards (n 17).

${ }^{198}$ Ibid., 506-507. My square brackets.

${ }^{199}$ Such as undue influence or laches. See E. Sherwin, "Constructive Trusts in Bankruptcy" [1989] U of Ill. L Rev, 297, 3601.

${ }^{200}$ Worthington (n 18) 228.

${ }^{201}$ Ibid., 228: the vendor elects between the two.

202 Rotherham (n 121) 170; The Law of Personal Property (n 105) 7-081; Chang v. Registrar of Titles (1976) 137 CLR 177, 184 189; Coffey v. Brunel Construction Co. Ltd. [1983] IR 36 [40], [43].

${ }^{203}$ Mackreth v. Symmons (1808) 15 Ves. 329, 340; [1808] 33 ER 778, 782 cited and approved in Hewett v. Court (1983) 46

ALR 87, 645 per Gibbs C.J.
} 
"may arise because of the relationship between the parties". ${ }^{204}$ The general criteria for equitable lien were set out by the High Court of Australia 205 and, as Deane J explains, "an equitable lien to repayment [or prepayment] of instalments of purchase prices [are] only of real value if specific performance of the contract would not be decreed". 206 While the lien is one of the equitable interests arising under the VPCT it can arise separately as a general equitable remedy such that they are not mutually exclusive, and an understanding of them, and their jural separation from the VPCT, increases the scope of available rights/remedies for the vendor or purchaser claimant, as the case may be.

[58] The purpose of the vendor's lien is to ensure he receives payment by completing the contract, it does not however enable one to get the land and is but another interest or protection arising under the trust to protect against betrayal. ${ }^{207}$ If part-payment occurs the lien secures the outstanding amount, however payment is not a prerequisite. If the contract is enforceable Equity treats the purchaser as the owner. Equity has by that point converted the beneficial estate to the purchaser, and the interest in the estate has been given proprietary consequences due to enforceability. ${ }^{208}$ By analogy Equity treats the effect of passing property in the beneficial estate in the same way as the common-law does should the vendor transfer the land and register legal title without payment. ${ }^{209}$ In summary, a vendor's-lien arises at stage (b) as the vendor has a right to the remaining or outstanding purchase money, ${ }^{210}$ stage (d) if the estate is conveyed but no payment made, ${ }^{211}$ and can exist at stage (c) if the contract is enforceable. However, it will not exist at stage (e) as neither party will exercise their chose.

[59] It is my conclusion that the vendor can assert a lien over the property still in his possession for the outstanding purchase price even if no part of the price has been paid. ${ }^{212}$ However, this is only in a small number of circumstances and so long as the purchaser has manifested performance of some of the terms in furtherance of the contract. Often this will be paying a deposit, meaning that the vendor maintains a lien for the outstanding purchase price; however if, for example, gaining planning permission is material to contract (and more so than part payment), then this could be sufficient evidence of exercising the chose. Thus, the agreement is given proprietary effect and purchase money is outstanding because the vendor can prove that the purchaser has a formed equitable interest (no longer mere). In Hewett v. Court Gibbs CJ said that, unlike the common-law lien:213

"A vendor's [equitable] lien for unpaid purchase money has been said to be founded on the principle that "a person, having got the estate of another, shall not, as between them, keep it, and not pay the consideration".'”214

[60] In this instance, referring to the beneficial/equitable estate which the purchaser has obtained, and on my analysis, has been given proprietary effect by conduct (exercise of the chose), Deane J further contextualised the availability of the lien, finding that: ${ }^{215}$

"The question whether the appellants had, at the relevant time, an equitable lien over the [property] falls to be determined by reference to the circumstances, including the provisions of the contract, and to general equitable principles".

${ }^{204}$ Hewett v. Court, 646 per Gibbs C.J. citing Sykes, Law of Securities, (3 ${ }^{\text {rd }}$ ed., Lawbook Company, 1978) 164-167; W.F. Webster, Ashburner on Mortgages (2 ${ }^{\text {nd }}$ ed., Butterworths, 1911) 112-125 and Halsbury's Laws of England (4 $4^{\text {th }}$ ed., 1987) vol. 28, 566-573.

${ }^{205}$ Hewett $v$. Court (n 207) 668: actual or potential indebtedness, specific property, unconscionability; approved in the UK In Re Bank of Credit and Commerce International S.A [1997] 3 WLR 909, [1998] AC 214, 226.

${ }^{206}$ Hewett v. Court, 668.

207 The Law of Personal Property (n 206) 15-120; Oakley Constructive Trusts 1993 (n 78) 292: "During his trusteeship, the vendor is clearly entitled to remain in possession of the property until completion and acquires an equitable lien on the property for payment of the purchase money". See Re Birmingham [1959] Ch 532; Cope (n 78) 936; Megarry and Wade (n 42) [24003]; Worthington (n 18) disagrees at 9.3.3.

${ }^{208}$ Akers v Samba (n 67) [63]; Worthington (n 18) 231 fn 46, as the purchaser acquires beneficial interests.

${ }^{209}$ S.R. Scott, "The Constructive Trust and the Recovery of Advance Payments - Neste Qy v. Lloyds Bank Plc" (1991) 14 NZ

ULR 375, 388; J. Hardingham, "Equitable Liens for the Recovery of Purchase Money" (1985) 15 MULR 65, 67-68.

${ }^{210}$ Lysaght v. Edwards (n 17) 506.

211 Snell (n 14) 44-005.

${ }^{212}$ See M. Pawloski, J. Brown, "Contracts for the Sale of Land and Personal Property" (n 81) 40, where they conclude that the vendor can remain in occupation and at the same time has a lien for any purchase money unpaid.

${ }^{213}$ Hewett v. Court (n 207) 90-91; cf Combe v. Swaythling (Lord) [1947] Ch 625, 628.

${ }^{214}$ Relying on Mackreth $v$ Symmons (1808) 15 Yes 329 at 340; 33 ER 778, 782.

${ }^{215}$ Ibid., 104 per Deane J. 
[61] Rotherham likewise concludes that "[v]endors enjoy a lien over the property in question until they receive the purchase price. This right arises by operation of law to ensure that this particular form of trust has relatively limited consequences in the event of insolvency. Should the buyer become insolvent, the lien gives the unpaid seller [vendor] the status of a secured creditor". 216 Professor Worthington takes the exact opposite view: that the vendor's lien only arises to secure outstanding funds if the purchaser has conveyed the property (and registered title) and the vendor has not received what is owed (the funds). This could only occur in the most unusual and impractical of circumstances ${ }^{217}$ and only fraudulent registration comes to mind. I argue that this comes down too far on the side of the more formal common-law lien, with the equitable lien unconcerned with possession (such that it matters not that the vendor is still in occupation or has legal title of the subject matter of the lien) but greatly concerned with protecting the obligation justly due. The obligation to pay the outstanding amount is justly due in Equity because the purchaser has entitlement to the equitable estate, and the vendor can assert that this interest is clearly proprietary due to part payment, material fulfilment of a relevant term, a chose being actioned or, more rarely, because the purchaser is in situ on the land (pending conveyance). ${ }^{218}$

\section{Illustrative Modern Cases}

\section{Jagdeo Sookraj v. Buddji Samaroo}

[62] In 2005 the Privy Council heard a VPCT case between two competing purchasers on appeal from Trinidad and Tobago. ${ }^{219}$ In the unanimous Jagdeo Sookraj v. Buddji Samaroo judgment220 ("Jagdeo") the committee distinguished between trusteeships arising because of a specifically enforceable contract and an equitable lien or charge existing due to payment of the purchase price, holding that: 221

"A purchaser who enters into a specifically enforceable contract for the sale of land acquires an equitable interest in the land and retains that interest for as long as the contract remains enforceable. On making pre-completion payments on account of the price the purchaser acquires also an equitable lien on the land to secure their repayment (subject to any set-offs and possible forfeiture of the deposit) if the contract goes off. [P1's] equitable interest in the present case arose on 3 November 1980, the date of the agreement. [P2] acquired an equitable interest on 8 January 1981, the date of his agreement, and further equitable interests when he made payments on account of the purchase price payable under his agreement. But [P1's] equitable interest, being earlier in time, has priority over all these equitable interests of [P2]".

[63] The arguments advanced here are both consistent with the Committee's reasoning and recommendation and offer a valuable rubric by which to give the VPCT clarity. Conversion occurred on 3 November when the parties contracted, and beneficial title was called into existence and impressed upon P.222 The subject matter of the VPCT was each party's mere equities and chose to enforce the contract; all were called into existence on 3 November. The Committee determined the contract enforceable contemporaneously; this was accepted as they found that $\mathrm{V}$ could make title and P could pay. On my analysis this is enough to give the mere rights proprietary effect. P exercised his chose by making part-payment and, even if he had not, he was always willing and able

216 C. Rotherham, Proprietary Remedies in Context (n 121), 170

217 It is further noted that "[t]he reason for restricting vendors' liens on sale property to contracts which are specifically enforceable has never been satisfactorily explained" although I have not found such a restriction nor is it evident in Hewett $v$. Court (n 207), Worthington (n 28) 231-2.

218 If the money is unavailable an interim possession order under CPR 55 could partially remedy such a situation.

219 Jagdeo Sookraj v. Buddji Samaroo [2004] UKPC 50; [2005] 1 P\&CR DG11 (henceforth Jadego).

${ }^{220}$ Comprising Lord Nicholls, Lord Steyn, Lord Millett, Lord Scott, and Baroness Hale.

${ }^{221}$ Ibid., [15] for simplicity, parties/purchasers names changed to P1 and P2.

${ }^{222}$ DKLR Holding Co (No 2) Pty Ltd v Commissioner of Stamp Duties (NSW) [1982] HCA 14, [8] per Brennan J. 
to pay. ${ }^{223}$ On making pre-payments a purchaser's lien arose ${ }^{224}$ and, although not stated, as soon as the contract was enforceable (3 November) so did the vendor's. ${ }^{225}$

[64] The dispute arose as an agent of the vendor mistakenly contracted with P2 on 8 January the next year and accepted a deposit. At that time P2 acquired a lien for his deposit and, like P1, equitable interests in the property; however, these ranked lower than P1 if P1 exercised them (which he did). If P2 had enforced the agreement prior to P1, and without notice, he would be Equity's darling, and P1 would only be able to trace into the vendors' funds.

[65] The Committee, unlike the argument advanced here, does not distinguish between conversion and enforcement, and on the facts, this makes little difference as enforcement was clearly possible because money was paid (and the outstanding amount presumably available). A more rigorous analysis of the facts would have been necessary if $\mathrm{P} 1 \mathrm{had}$ not made pre-payments as he would need to prove at that stage, prior to P2's contract, that he was willing and able to pay or, on the analysis advanced here, have sufficiently performed a material contractual term to manifest partperformance (such as gaining planning permission) which would crystallize his equities akin to partpayment/deposit.

[66] Dr Turner concludes that at the pre-payment stage (P1 in Jagdeo), "the purchaser's interest in the land affords much less than equitable ownership." 226 This is correct so long as P1 chooses not to enforce his ownership, on my analysis, by exercising his chose. Conversely the editors of The Law of Personal Property note that the question of timing and priorities (as was the issue in Jagdeo) is difficult, and they controversially, and in my view incorrectly and against authority, prefer a restrictive lien alone argument that, pending full payment:227

"the property is not held on [vendor-purchaser] constructive trust for the purchaser; rather, the purchaser has an equitable lien on the property to ensure repayment of the deposit and any other compensation that may be payable by the vendor if the contract does not proceed to completion. Only when the contract is unconditional is it regarded in equity as specifically enforceable, and only then will the vendor be regarded as holding the property on constructive trust for the purchaser".

[67] Equity does not circumscribe the rights and remedies of its supplicants, seemingly because it produces a neater taxonomy. On my analysis it is preferable not to restrict rights/remedies and leave the mutual interplays of the doctrines - constructive trust, lien, conversion, chose in action, mere equity, equitable interests, enforcement and, as partially touched on, equitable estate theory, 228 open. This is especially the case when they are germane.

\section{Scott v. Southern Pacific}

[68] Scott v. Southern Pacific address fundamental land law and priorities questions. Some see it as a case best footed in estoppel ${ }^{229}$ but as a VPCT case it has far-reaching consequences as to the effect of equitable rights in specie, on third parties, and on doctrinal issues. ${ }^{230}$ Lord Collins held that "it does not follow that the purchaser has proprietary rights for all purposes", 231 relying on Lord Cottenham

\footnotetext{
${ }^{223}$ Ibid,. [11], [15].

${ }^{224}$ The Law of Personal Property (n 206) 15-119; Worthington (n 18) 227-229.

${ }^{225}$ Ibid., 231 fn 46.

226 Turner (n 4) 587-88.

${ }^{227}$ The Law of Personal Property (n 206) 15-063: This is one of Professor Worthington's chapters and this part in particular follows similar reasoning to that taken in her Proprietary Interests in Commercial Transactions.

${ }^{228}$ R.M.P Willoughby, The Distinctions and Anomalies Arising Out of the Equitable Doctrine of the Legal Estate (CUP, 1912) 6,71-72.

${ }^{229}$ Scott v. Southern Pacific Mortgages [2014] UKSC 52 (elsewhere known as the North-East Property Buyers Litigation); for a discussion of the estoppel implications see Andreas Televantos and Lorenzo Maniscalco, "Proprietary Estoppel and Vendor Purchaser Constructive Trusts" (2015) 74 CLJ 27; For the distinction between CT and estoppel see M. Dixon "More Moves in constructive trusts and estoppel" (2017) Conv 89: Professor Dixon earlier arguing that "proprietary estoppel should not become the penicillin of equity" in "Proprietary estoppel: a return to principle" (2009) Conv 260.

${ }^{230}$ Scott, [65].

${ }^{231}$ Ibid.,
} 
LC, who stated that "the rule by which a purchaser becomes in equity the owner of the property sold "applies only as between the parties to the contract, and cannot be extended so as to affect the interests of others."'”232 Lord Collins surprisingly concluded in Scott that, as opposed to any equitable rights arising in the contracting period:233

"the vendors acquired no more than personal rights against the purchasers when they agreed to sell their properties on the basis of the purchasers' promises that they would be entitled to remain in occupation. Those rights would only become proprietary and capable of taking priority over a mortgage when they were fed by the purchasers' acquisition of the legal estate [title] on completion[...] with the effect that the acquisition of the legal estate and the grant of the charge would be one indivisible transaction, and the vendors would not be able to assert against the lenders their interests arising only on completion". ${ }^{234}$

[69] This apparent sea change in the law of property recasts the question of what specific equitable interests are acquired by the purchaser during the contract to conveyance period and what their effects on third parties are. Strict application of $S$ cott would hold that the party with beneficial title (equitable estate), the vendor in Scott but the purchaser in most other instances, is limited to personal (in personam rights) which are incapable of binding third parties. One might now ask, what then is a trust and what of its ostensibly settled proprietary consequences?

[70] In Scott, prior to conveyance and as a condition of sale, the purchaser agreed to let the vendor remain in the property for life but did not inform the third-party mortgagee. After conveyance and registration of the mortgage, when the mortgagor/purchaser went into default and the mortgagee tried to foreclose on the former vendor, she asserted a proprietary right against the third-party mortgagee. The conclusion was that at no time did the vendor acquire rights of a proprietary nature - the right to live in the property as an equitable life interest ${ }^{235}$ turned on the finding by the Supreme Court that the purchasers "[lacked] so-called scintilla temporis - in which the purchaser acquired the unencumbered legal estate". $236 \mathrm{~A}$ mere 'sliver of time' can create many issues where an intervening equity or trust (e.g. a life interest) can arise and take effect between purchase and creating the mortgage or charge. Years previously, in Abbey National v. Cann, the House of Lords put this intervening issue of mere seconds to rest, rejecting scintilla temporis and finding the finance purchase and charge temporally indivisible. ${ }^{237}$ Here the Supreme Court was concerned that in the seconds between purchasing the property and registering the charge any tenant's (or other's) equity could bind the unknowing mortgagee such that it would have a mass chilling effect on property finance. ${ }^{238}$

[71] In accordance with Cann the Supreme Court held that, as the purchaser did not have full beneficial title and legal title before conveying the assignable equitable right to Mrs Scott, they could not grant the proprietary right to live in the house for life (back) to the vendor. Lady Hale held (relying upon the judgment of Lord Oliver in Cann):239

"Of course, as a matter of legal theory, a person cannot charge a legal estate that he does not have $[\ldots]$ Nevertheless, I cannot help feeling that it flies in the face of reality. The reality is that, in the vast majority of cases, the acquisition of the legal estate and the charge are not only precisely simultaneous but indissolubly bound together. ${ }^{240}$ The acquisition of the legal estate is entirely dependent upon the provision of funds which will have been

232 Ibid., quoting Inland Revenue Commissioners v. G. Angus \& Co. (1889) 23 QBD 579, 595, himself approving Lord Cottenham LC in Tasker v. Small (1837) 3 My \& C 63, 70.

${ }^{233} \operatorname{Scott}(\mathrm{n} 21)$ [79].

${ }^{234}$ This question arose owing to the unusual facts of Scott but the principle is applicable vice versa.

${ }^{235}$ An assignable equitable right, unassignable at common law.

${ }^{236}$ Scott, per Lady Hale, [109] (emphasis added).

${ }^{237}$ Abbey National Building Society v. Cann [1991] AC 56 (HL), 92 per Lord Oliver.

${ }^{238}$ P. Feltham, T. Leech, P. Crampin, J. Winfield, Spencer Bower: Reliance-Based Estoppel (5th ed., Bloomsbury, 2017 ) 9.51.

${ }^{239}$ Ibid., [110] citing Cann p. 92.

${ }^{240}$ Lord Hoffmann decried the logic of any theory based on the notion of scintilla temporis in Ingram v. IRC [2000] 1 AC 293,

303 (HC) doubting those as having "[not] a very powerful grasp on reality". 
provided before the conveyance can take effect and which are provided only against an agreement that the estate will be charged to secure them".

[72] In Lady Hale's opinion as the interest of the mortgagee arose upon registration of the conveyance, both simultaneous, the purchaser could not assign interests because the mortgagee already held part of the beneficial estate. Yet the way she phrased her decision appears an overly convoluted nemo dat argument (one cannot give better title than one already has), and goes far further than Cann's rejection of scintilla temporis and dicta of a mere indivisible tripartite vendor, purchaser and mortgagee charge/attachment in its rejection of Mrs Scots life interest.

[73] Lord Collins' decision in Scott is consistent with his earlier position in Englewood Properties Ltd. v. Patel.241 That case concerned the sale by a property developer of a lot of shops which, it transpired, were subject to restrictive lessors' covenants as between the shop owners. As the benefits of the covenants were not vested in the vendor developer (but were equitable between the lessees of the shops) they were not part of the estate being sold; therefore they were not held on trust by the vendor. ${ }^{242}$

[74] The reasoning in $S$ cott has been criticised. The editors of Emmet $\approx$ Farrand on Title emphasise that: ${ }^{243}$ "the reasoning that a purchaser of land acquires an insufficient equitable interest to create proprietary rights was misconceived [...] its unprincipled impact could be confined to similar proprietary estopples [sic] cases, but the judgments are expressed as relating to the grant of proprietary right without such a restriction".

[75] Even more concerning, Lady Hale went further than Lord Collins in seeming (as written) to discount Equity as a jurisdiction, holding that "The [ $3^{\text {rd }}$ party] lender is not a party to the contract to sell the land to the purchaser. This is an entirely separate matter between vendor and purchaser in which the lender is not involved". ${ }^{244}$ This might be true at Law but it is not the case in Equity. Whether her statement can be confined to the facts or is of broader application is yet to be decided and will most likely be brushed aside. On a literal reading its consequences are concerning.

[76] A plausible construction of the facts is that $S$ cott is a case regarding priorities, that the first equitable interest which arose was to the mortgagee, and then the next (and second ranked) was the life interest to Mrs Scott. ${ }^{245}$ However, this is difficult to maintain as the sale of the house was contingent on the grant of the life interest, as either an estoppel or as a general unconscionable bar. The life interest was at minima in conception before the sale contract was signed, and before a mortgage could be registered. The post-Cann tripartite indivisibility of purchase/charge/registration is seemingly not relevant based on these facts as Mrs Scott only entered into the transaction and pre-contractual negotiations on the basis of her 'guaranteed' life interest and monetary compensation - not in order to surprise a mortgagee. The court's policy objective of avoiding the economically devastating situation where banks and building societies would be unwilling to advance funds to purchase property due to 'off book' (or equitable) liabilities/interests ${ }^{246}$ is seemingly irrelevant as the group of appeals was limited to lenders who had not completed proper due diligence, and regulatory intervention had already banned nefarious sale and rent-back schemes. ${ }^{247}$ Sans policy, it is arguable that prior to contract Mrs Scott as vendor with the whole equitable estate assigned this equity to the purchaser for the purpose of it being assigned back to her. Secondly, this is not what a plain reading of the judgment holds.

[77] Scott could be rationalised along the argument advanced in this paper, that Mrs Scott had a mere equity or a chose only effective between her and the purchaser - the life interest - and she needed to give it proprietary consequences as against third parties who had no notice of it by way of an injunction. This is not, as Emmet \& Farrant suggest, an "insufficient" equity but a mere one - mere

\footnotetext{
241 [2005] EWHC 118 (Ch); [2005] 1 WLR 1961.

242 Ibid., [58].

${ }^{243}$ J. Farrand and A. Clarke, Emmet \& Farrand on Title (Sweet \& Maxwell, March 2017) 5.119.01.

${ }^{244}$ Scott, [116].

245 This is how Davies and Virgo summarise the case in Equity and Trusts (n 72) 353.

${ }^{246}$ Spencer Bower: Reliance-Based Estoppel (n 254) 9.51.

${ }^{247}$ Financial Services Authority, Sale and Rent Back Review 2011 (January 2011); Regulated in 2009 under s 19 Financial Services and Markets Act 2000.
} 
because it arose out of a contract she had with her purchaser, a contract specifically disentitling her. If the mere equity arose out of her dealings with the purchaser, and arose before the mortgagees' interest but is not given proprietary effect, her relief, as was the case, was personal and limited to an adjustment of the rights between her and the purchaser, a judgment-proof debtor. If the mortgagee had notice then it would be subject to the equity, and as the mortgagee did not then the equity did not survive as against them.

[78] As noted, case-law unfortunately suffers from a lack of adequate nomenclature (or its sophistication) to conceptualise the interests such that cogent precedent could develop, and support must be read-in. The rise in middle-class home-ownership in the nineteenth century 248 saw a litany of VPCT claims pass through Chancery and a recognition, but not application, of the different creatures of equitable rights. Baldwin v. Belcher postulates that, "It could be that the purchaser is only recognised as beneficial owner for the purposes of disposition". ${ }^{249}$ This goes both to the nature of the equity arising and its assignability, so that the purchaser might only assign for the purpose of obtaining the estate (e.g. assign to another party for the purpose of raising a loan). A more nuanced reading of the case might suggest that mere equities do not bind third parties until actioned and given proprietary effect (e.g. until it is known that contract is enforceable and thus the estate disposable).

[79] The influence of the 1970s Denning line of remedial (or unprincipled) constructive trust cases cannot be underestimated. Scott is noticeable for bearing factual similarity with his much-criticised judgment in Binions v. Evans, ${ }^{250}$ where he was prepared to find that conveyance subject to an existing tenancy gave rise to an equitable interest even where the party did not have an equitable interest prior to the conveyance. It was an equity of his on making, in situ, on the bench. The interests bound third parties, Denning essentially creating property rights. ${ }^{251}$ The sometimes-important theoretical distinction between imposing an injunction restraining a party from evicting a tenant, and declaring that the said tenant has a proprietary right in the form of a constructive trust makes little practical difference to the tenant. 252 However, in the Equity jurisdiction "fears of damaging the fabric of property law" 253 is a consideration found in the viewpoint that the constructive trust is a variant of declaratory judgments. ${ }^{254}$

[80] If $S$ cott were applied as read the law of property and priorities would be subject to such wholesale revaluation that Equity would play little part as the very existence of beneficial rights was denied. ${ }^{255}$ I sincerely doubt this was the intention of the Supreme Court, but it is how the case reads.

\footnotetext{
${ }^{248}$ M. Ball and D.T. Sunderland, An Economic History of London: 1800-1914 (Routledge, 2001) 186, 337.

${ }^{249}$ Baldwin v. Belcher (1844) 1 Jo. \& Lat. 18, 26.

${ }^{250}$ Binions v. Evans [1972] Ch 359.

${ }^{251}$ Rationalised on the judgment of Cardozo J in Beatty v. Guggenheim (1919) 225 NY 380, 385: "conscience of equity finds expression", and Lord Diplock in Gissing v. Gissing [1970] 2 All UKHL; 2 All ER 780. To which R.P. Meagher retorts in Future Directions in Equity (1985) (n 11) that equity in England “...is heading through a present state of chaos and moving towards ultimate doom, unless some steps are taken about it which would include the removal of Lord Denning's influence and the extermination of Lord Diplock!", 20.

${ }^{252}$ R. P. Meagher and W. M. C. Gummow, Jacob's Law of Trust in Australia (5 $5^{\text {th }}$ ed., Butterworths, 1986) 321.

253 J.D. Davies, "Informal Arrangements Affecting Land" (1979) 8 Syd. L.R. 578, 583.

${ }^{254}$ Where the argument is such that when the court states "The Constructive Trust arises by operation of law" it is simply saying that its role in the case is declaratory, and to point to the time it came into existence because of the facts identified, and to explain the consequences: Westdeutche Landesbank (5), per Lord Browne-Wilkinson; PW Young, Declaratory Orders (1st edn, Butterworths 1975) [1602] identifies the VPCT as a declaratory order; K Dharmananda and A Papamatheos (eds), Perspectives on Declaratory Relief (Federation Press, 2009) 67, 108; A Mason, 'Declarations, Injunctions and Constructive Trusts: Divergent Developments in England and Australia' (1980) 11 UniQldLJ 121, 129; See Rotherham (n 119) 307; Editorial, "Tipping off: Establishing a Constructive Trust Not Necessary in Order to Obtain a Declaratory Judgment" (2001) 7 Trusts \& Trustees 39; Re Stucley [1906] 1 CH 67, 75-76 per Vaughan Williams LJ; G.W. Keeton, The Law of Trusts (9th ed., Pitman, 1967) 202; Re Plymouth Corp and Walter [1918] 2 Ch 354; Bridges v. Mess [1957] Ch 475; See Meagher, Gummow, and Lehane (1975) (n 1) [1915].

${ }^{255} \operatorname{Scot}$ (n 21) [116] per Baroness Hale.
} 


\section{Conclusion}

[81] This paper advances views which could be considered controversial, although I am by no means the first to advance them. They are that this category of constructive trust arises on contracting, that it is a conditional trust of a chose which, if executed, gives proprietary consequences, and that the vendor obtains a lien for the outstanding purchase money (without the property necessarily being conveyed). Some contemporary and historical cases support these conclusions, and others reject them outright. It is an area of great contention but also of use in practice. Commentators may take solace in the fact that the approach to the VPCT and the fundamental questions of its doctrine by the highest authority has of late been simply to ignore them. Mason J in Chang v. Registrar of Titles found: "It is enough to say that it has been accepted in decisions in England and Australia that at least when the purchaser has paid the purchase money the vendor becomes a constructive trustee of the property sold". ${ }^{256}$ That conclusion is hardly the point, however. That Chancery practitioners know now that $\mathrm{X}$ is a trustee does not help us greatly if an adverse obligation arose in the past, nor does it help us understand the doctrine. That we cannot state when the trust arose does call the institutional nature of the doctrine into question. In Central Trust and Safe Deposit Co Lord Parker, giving the recommendation of the Privy Council on a case from Canada, identified the temporal issue which is at the heart of the VPCT concept:257

"If for some reason equity would not enforce specific performance, or if the right to specific performance has been lost by the subsequent conduct of the party in whose favour specific performance might originally have been granted, the vendor or covenantor either never was, or has ceased to be, a trustee in any sense at all'.

[82] This is not a legal fiction but recognises a style of legal analysis hard to come to terms with. The UK Law Commission identified this temporal conceit in its review of Transfer of Land: Passing of Risk. from Vendor to Purchaser. The traditional view is that the VPCT arises because of susceptibility to specific performance 258 - which I conclude is both an oversimplification as the VPCT protects the equitable interest in not being betrayed, as opposed to enforcements contractual performance focus. A more delineated view is that as at the time of contract the parties are conditionally or "potentially entitled to specific performance" such that "greater regard should be had to the question of whether specific performance actually would be ordered than to whether, in theory it might be". ${ }^{259}$ This too is problematic although technically astute. When the trust first arises there is clearly no unconscionability; thus it is often argued that the VPCT shares little lineage with all other constructive trusts as unconscionability is not apparent at first instance. ${ }^{260}$ The argument advanced here is that this is incorrect as unconscionability will exist should the trust relationship be relied on to protect an interest (as one party is unconscionably denying another's right), because a betrayal has occurred or can occur. Yet of the trust at the start, where there is no unconscionable conduct between the two parties at that temporal instance, it can be argued that the relationship is later categorised by the court in its declaratory function to guard against later unconscionability and betrayal should it occur, with the relevant instrument being the contract. ${ }^{261}$ However this only needs to be advanced if one doubts the VPCTs jural lineage in constructive trust discourse, a consideration I don't think tenable on any definition of constructive trust, given that the VPCT is the oldest variant and land is the most precious property that law can protect.

[83] The question of when the trust arises is always asked and answered from a post hoc perspective; that is, the court looking back over the span of the parties' relationship. For example, should parties contract and two days later the vendor refuses to accept a deposit payment and the purchaser seeks

256 (1976) 137 CLR 177, 185.

${ }^{257}$ Central Trust and Safe Deposit Company v. Harvey G. Snider \& ors [1916] 1 AC 266 PC (Canada), 272 [my emphasis].

258 The Law Commission, "Transfer of Land: Passing of Risk from Vendor to Purchaser" (HMSO, Working Paper 109, 1988) 1.43 .

${ }^{259}$ Law Commission WP109, 1.45.

${ }^{260}$ G. Virgo, The Principles of Equity and Trusts (n 10) 325.

${ }^{261}$ Along a more general argument as per Professor Ong below it could be advanced that all constructive trusts arise on some condition precedent, either unconscionability, a set of facts, change in beneficial title or some other factor etc. 
both declaration and injunction from the court ${ }^{262}$ the temporal perspective will be from either the time of suit or the time of the last relevant event. Applying the dicta of Lord Parker, at the day of contract there was no subsequent conduct militating towards Equity granting specific performance. Or on the analyses in this paper neither party had exercised the chose, or right of access to court declaration and enforcement, to give proprietary effect to their equities/interests. If the vendor had sold the property for value and without notice to another on day one then the equitable interest of the original purchaser paying on day two would rank below (be lost in the property but traceable to the funds). However, if there were just the two original parties $(V \& P)$ then attempting to pay the deposit on day two would satisfy the requirement of subsequent conduct, turning the agreement proprietary. The point here is that, firstly, the availability of specific enforcement is not a theoretical enquiry but a factual one, and secondly that the court's declaration of proprietary rights is not discretionary because the rights arise by actual conduct. One might retort and suggest that the purchaser, knowing full well that vendor no longer wished to sell, could always attempt to perform the contract, and in this example, it would always be a fait accompli that proprietary effect would be given. However, if the vendor had indicated that he wished to void the agreement on day one then the purchaser attempting to pay on day two could not give that agreement proprietary effect; courts will not always grant enforcement and only will do so if the estate has split (due to betrayal or unconscionability) and can be rendered whole by a declaration.

[84] There are multiple views as to when the trust arises or when beneficial ownership transfers; this can be ascribed to misinterpretations of old precedent and exigencies in language, especially regarding our understanding of beneficial title and who 'has or owns' it. ${ }^{263}$ However, as noted earlier, this paper distinguishes between the trust arising on contract and the purchaser obtaining a non-proprietary beneficial interest, and then the latter proprietary effect given (or not) to that relationship and the interests stemming from it, such that these views - due to the new distinction - are not so dichotomous. There is much work to be done as to the importance of the courts declaratory powers which are a core part of the constructive trust. The VPCT arises, the parties give it proprietary effect, one party refuses to perform their obligation, the parties go to court, and the court enforces a judicial transfer/sale. The court is not acting retrospectively, it is simply declaring that the trust did indeed arise and subsequent conduct by the parties gave the rights/obligations under the trust proprietary consequences - logically these take/vest from the time the trust arose. Some support for this can be found in historical cases. In White v. Ball Sir Thomas Plummer MR found that he could not describe the vendor as a "trustee" from the time of contract without qualification and therefore described the vendor as "trustee sub modo" 264 from that point, meaning that the vendor is a potential or conditional trustee on contracting but only an actual trustee when the money is paid (at which point the law would hold him bound to convey). ${ }^{265}$ Support is also found in the writings of I.C.F Spry, who concludes that "...courts with equitable jurisdiction [often] prevent the setting up of facts that are inconsistent with the existence of an enforceable contract at law, and on this basis there is a grant of specific performance". ${ }^{266}$ As to the temporal nature of courts' analysis, Spry notes that:267

"it is not regarded as necessary that courts with equitable jurisdiction should progresses by stages and so require separate proceedings for the establishment of legal contractual rights and then, subsequently, for the enforcement of those rights by an order for specific performance. It is sufficient simply to apply for an order of specific performance and to establish on that application the matters through which the defendant should be prevented

\footnotetext{
${ }^{262}$ A mandatory injunction preventing the vendor from conveying the property or destroying it, and a declaration that the property is held on trust and the ultimate injunction of specific enforcement of the conveyance.

${ }^{263}$ See Law Commission WP109, 1.47; Ibid. 501, 503; See also Dowson v. Solomon (1859) 1 Drew. \& Sm. 1, 9 per Sir Richard Kindersley V-C.

264 (1820) 1 Jac. \& W. 494: meaning under condition.

${ }^{265}$ Law Commission WP109, 1.47

${ }^{266}$ I.C.F. Spry, Equitable Remedies $\left(9^{\text {th }}\right.$ ed., Sweet \& Maxwell, 2014) 55.

${ }^{267}$ Ibid.,
} 
from relying on a ground by the legal enforceability of the contract might otherwise by impugned".

[85] Likewise, in Bridges $v$ Mees Harman $\mathrm{J}^{268}$ regarded a vendor of land as becoming a trustee of the legal estate on entering into the contract, and a "mere trustee of the legal estate and must convey it"269 when all instalments of the purchase price had been paid. Harman J accepted the purchaser's claim that he was beneficially entitled to the land in fee simple ${ }^{270}$ and handed down a "declaration that he is the owner in fee simple of the disputed land", due to the bare trust, and ordered that the register be rectified. 271 In Freemoult v. Dedire it was "decided that a covenant to settle lands makes the covenantor but a trustee for the parties who would be interested if the covenant were performed", ${ }^{772}$ such that the covenant and its proprietary consequences were conditional, and that decision was a "logical consequence of the power of a Court of Equity to grant, and its practice in granting, specific performance of a contract to convey or settle real estate". 273 Professor Ong comes to a similar conclusion as advanced in this paper, but expressed in different descriptive terms. He concludes that the VPCT is a "condition precedent constructive trust"274 (I suggest that might properly be the betrayal interest), and provides the following definition: ${ }^{275}$

“.... an equitable interest in land may be acquired by a purchaser who... is able to obtain an injunction to protect his interest under that contract [of sale]... it has been held...that a purchaser under a contract for the sale of land which was subject to a condition precedent with respect to its performance, because he was entitled to protect his interest under the contract by injunction, obtains, by virtue of that conditional contract, and equitable proprietary interest in the land. On principle, a purchaser under such a conditional contract of sale thereby becomes a constructive beneficiary sub modo (under condition)".

[86] Therefore, by way of re-definition, I argue that the vendor purchaser constructive trust comprises equitable interests held on trust which arise by parties contracting for the sale and purchase of property susceptible to the remedy of specific enforcement, that is, unique property where damages would not compensate. This conditional trust protects the purchaser's equities in performance of the contract, and protects them against betrayal, during the contract-to-completion period (registration/conveyance), whilst also protecting the vendor's interests in having the sale completed (another betrayal interest). The primary interest held on the trust is a mutual chose which, if exercised by one or both, gives proprietary effect to the equitable interests - that is, the parties may seek a declaration. The trust arises as soon as the contract is made, when equitable conversion simultaneously occurs, and the purchaser becomes beneficially entitled to the equitable estate, which transfers to him in stages. Likewise, the vendor becomes entitled to the outstanding purchase monies; however, this entitlement is often not yet proprietary. When the contract is completed by way of full payment and/or of all the terms the VPCT collapses and a bare trust arises and beneficial entitlement in the property proper is vested in the purchaser absolutely, and this trust in the usual sense binds third parties and equitable interests are assignable. ${ }^{276}$ The vendor will often maintain an equitable lien for the outstanding purchase money from the moment the contract becomes enforceable; likewise, the purchaser has a lien on the property for any purchase money paid until the land is conveyed/registered. The vendor owes specific duties to the purchaser, and

\footnotetext{
${ }^{268}$ Bridges v. Mees [1957] 3 Ch. 475, 485.

${ }^{269}$ Ibid., 486.

${ }^{270}$ Ibid., 476.

271 ibid., 487.

${ }^{272}$ Freemoult v. Dedire (1718) 1 P Wms 428 as applied in Central Trust and Safe Deposit Company v. Harvey G. Snider \& Ors [1916] 1 AC 266 PC (Canada), 271 per Lord Parker approving the reasoning of Meredith CJ of Ontario in the court below [my emphasis].

${ }^{273}$ Central Trust and Safe Deposit, 272.

${ }^{274}$ D. Ong, Trusts Law in Australia (4th ed., Federation, 2012) 616: although the VPCT is a specific type of condition precedent constructive trust said to operate on a condition precedent of unconscionable facts.

275 Ibid.,

${ }^{276}$ Except equity's darling, the bona fide purchaser for value without notice.
} 
these are classified as trustee duties but they exist only for the purpose of carrying out the contract of sale, such that he is a qualified trustee and his duties are only that of a fiduciary for the purpose of carrying out the transaction and not in any general sense. ${ }^{277}$ The purchaser may only assign his beneficial rights such that they bind third parties once his equities are given proprietary consequence through exercise of his chose, either by the contract becoming enforceable or through an injunction. If the vendor breaches the contract and sells to another party for value and without notice the purchaser may trace into the proceeds of the sale or claim damages from the vendor.

[87] Finally, what of the rationale for the VPCT? Dr Turner's justification is that the trust protects the reciprocal interests each party has in the contract being performed (which will often have been their original contractual intention), 278 and I do not doubt this but argue this is what the more general remedy of specific performance protects. Mr. Swadling criticises the VPCT, arguing that the only justification for its existence is, as Sir George noted, that it has existed for a long time. ${ }^{279}$ I conclude that the VPCT protects vital equitable interests that contractual rights at Law alone cannot, namely the interest both parties have in not having their mutual trust being betrayed - and that this is a species of unconscionability which can arise throughout a conveyancing transaction. Ultimately this produces the same result as Turner's thesis - ensuring performance, however it gives greater explanation for the existence of the equitable estate and interests, these being Equity's sin qua non. It also allows the VPCT to sit squarely within the plural rationale of all constructive trusts, viz a wider doctrine, which I advance along the lines of the courts declaratory function in informing parties what trust and property interests they have, and contextual unconscionability in the form of a response (or pre-emptive reaction) to unique inequitable events which Equity grants protection to or responds by operation of Law/Equity.

[88] To conclude, overt generalisations have led to greater complexities in the VPCT's operation. With this redefinition the VPCT can be properly viewed as a species of constructive trust, and this is illustrative of its wider purpose within the constructive trusts' genus: protecting and declaring equitable estate and beneficial entitlement. The main consequence is that in the event of the vendor conveying to a third party the purchaser/beneficiary may assert a proprietary interest in the proceeds ${ }^{280}$ or the land itself; 281 contract does not give this protection and it is unique to Equity. Similarity specific enforcement does not grant the added tracing protection either. By delineating the VPCT and further re-defining its operation during the transactional stages it is apparent that its utility is far greater than once thought; it previously appeared as a pleading of last resort due to its uncertain footing. ${ }^{282}$

[89] As the vendor-purchaser constructive trust is now offered firmer doctrinal footing, and shorn of definitional generalisations, ${ }^{283}$ it proves a concrete cause of action. Now, along with all other constructive trusts, the VPCT reveals an equitable proprietary entitlement, a beneficial estate or title that the constructive purchaser-beneficiary should not resile from asserting. For both parties, upon contract and upon exercising chose, land is money and money is land, and if betrayal arises recourse can be had to the constructive trust to identify and declare respective estates and entitlements.

\section{END}

${ }^{277}$ P.D. Finn, The Fiduciary Obligations (Law Book Co, 1977) 2 [3].

278 Turner (n 4) 604.

279 William Swadling (n 18) 487.

${ }^{280}$ And obtain any benefit in an increase in value of those proceeds.

${ }^{281}$ If the third party takes without value or has notice.

282 The tell-tale sign being the number of recent appellate cases all on the applicability of centuries of supposedly settled case law to the facts (Lysaght v. Edwards (n 17) 506), and not on overruling or new interpretation of the law itself. Jerome v. Kelley (n 16) [29] was at most a restatement of the stages of conveyance recognised in Lysaght (but with Turner's prosaic 'stage' phrasing) and not all successful as $S \operatorname{cott}$ (n 21) needed to restate the position again a decade later.

${ }^{283}$ In the latest text on CTs, Rationalising Constructive Trusts (Hart, 2017) by Y.K. Liew, the author concludes that the VPCT aim is both to protect each party's 'performance interest' [8.2.3] and this because the CT is a 'replicative remedy' [8.2.2]; See J. Meagher "Review: Y.K. Liew's Rationalising Constructive Trusts" (2018) KLJ 29(2) I submit that this falls into the definitional generalisation category and lacks the specific language of Chancery. 
